NBER WORKING PAPER SERIES

\title{
THE EFFECT OF CASH INJECTIONS: EVIDENCE FROM THE 1980S FARM DEBT CRISIS
}

\author{
Nittai K. Bergman \\ Rajkamal Iyer \\ Richard T. Thakor \\ Working Paper 23546 \\ http://www.nber.org/papers/w23546 \\ NATIONAL BUREAU OF ECONOMIC RESEARCH \\ 1050 Massachusetts Avenue \\ Cambridge, MA 02138 \\ June 2017
}

\begin{abstract}
We thank Daron Acemoglu, Jean-Noel Barrot, Douglas Diamond, Mike Duffy, Emre Ergungor, Mariassunta Giannetti, Radha Gopalan, Michelle Hanlon, Richard Hornbeck, Dirk Jenter, Nobuhiro Kiyotaki, Debbie Lucas, Atif Mian, Anna Mikusheva, Ben Olken, Jonathan Parker, David Robinson, Greg Salton, Antoinette Schoar, Alp Simsek, Jeremy Stein, James Stock, Anjan Thakor, Sharon Waltman, the Farm Credit System Associations, and seminar participants at HEC, INSEAD, IDC, MIT, Ohio State University, Oxford, Tel Aviv University, University of Minnesota, Washington University in St. Louis, the 2016 American Economic Association Meetings, the NBER Monetary Economics Summer Institute, and the Financial Intermediation Research Society Conference for helpful discussions and comments. We also thank John Schroeter and Iowa State University for their assistance with coordinating data collection. The usual disclaimer applies. The views expressed herein are those of the authors and do not necessarily reflect the views of the National Bureau of Economic Research.
\end{abstract}

NBER working papers are circulated for discussion and comment purposes. They have not been peer-reviewed or been subject to the review by the NBER Board of Directors that accompanies official NBER publications.

(C) 2017 by Nittai K. Bergman, Rajkamal Iyer, and Richard T. Thakor. All rights reserved. Short sections of text, not to exceed two paragraphs, may be quoted without explicit permission provided that full credit, including $\odot$ notice, is given to the source. 
The Effect of Cash Injections: Evidence from the 1980s Farm Debt Crisis

Nittai K. Bergman, Rajkamal Iyer, and Richard T. Thakor

NBER Working Paper No. 23546

June 2017

JEL No. D22,D24,D31,E23,E24,E51,G01,G21

\begin{abstract}
$\underline{\text { ABSTRACT }}$
What is the effect of cash injections during financial crises? Exploiting county-level variation arising from random weather shocks during the 1980s Farm Debt Crisis, we analyze and measure the effect of local cash flow shocks on the real and financial sector. We show that such cash flow shocks have significant impact on a host of economic outcomes, including land values, loan delinquency rates, the probability of bank failure, employment, and wages. Estimates of the effect of local cash flow shocks on county income levels during the financial crisis yield a multiplier of 1.63 .
\end{abstract}

Nittai K. Bergman

MIT Sloan School of Management

100 Main Street, E62-632

Cambridge, MA 02142

and NBER

nbergman@mit.edu

Rajkamal Iyer

Imperial College

riyer@MIT.EDU
Richard T. Thakor

University of Minnesota,

321 19th Avenue South, 3-255

Minneapolis, MN 5545

rthakor@umn.edu 


\section{Introduction}

A large theoretical literature exists showing that in the presence of financial frictions, weak firm balance sheets detrimentally affect economic activity (see e.g., Bernanke and Gertler 1989, 1995; Shleifer and Vishny 1992; Gertler and Gilchrist 1994; and Kiyotaki and Moore 1997). Strengthening firm balance sheets during a financial crisis is thus a much discussed and debated question. ${ }^{1}$ By reducing financial frictions, such interventions may increase investment, support lending, raise employment, and mitigate the severity of a financial crisis.

Estimating the economic effect of interventions meant to strengthen firm balance sheets during a financial crisis is a difficult task - the timing and strength of such interventions are likely to be endogenous and driven by the severity of the crisis itself. Since interventions generally occur in response to severe crises, a simple correlation would suggest, likely erroneously, that such interventions have detrimental effects on the economy.

To understand the effect of interventions that strengthen firm balance sheets during financial crises, we focus on the farm debt crisis of the 1980s. Assembling a yearly, county-level dataset of weather and farm data in Iowa, our identification strategy relies on exploiting variation arising from random weather shocks. As a large literature in agronomics shows, weather shocks affect crop yields and hence farm income. Geographic variation in weather realizations thus provide plausibly exogenous variation in local cash flow and are akin to cash injections to the farming sector operating within a county. In this paper, we analyze and measure the effect of such exogenous cash injections during a financial crisis on both the real and financial sector.

Spanning the period 1981-1987, the farm debt crisis resembled in many ways the financial crisis of 2008-2009, with agricultural land prices and farm debt - much of it collateralized by land -

\footnotetext{
1 See e.g. the substantial debate during the 2008-2009 financial crisis regarding the effectiveness of stimulus bills such as the Economic Stimulus Act of 2008 and the American Economy and Reinvestment Act of 2009, which, among other provisions, reduced firms' tax obligations and in so doing strengthened real sector balance sheets.
} 
increasing substantially prior to the crisis onset. Subsequently, during the crisis itself, land prices in the U.S. corn-belt plummeted by nearly 50 percent. The farming sector saw severe deleveraging - total agricultural debt declining by 29 percent from 1984 to 1988 - and experienced substantial disruptions with numerous farm bankruptcies as well as agricultural bank failures throughout the period. ${ }^{2}$

As a first step in our empirical analysis, we confirm that county-level weather variation is related to farm yields in our data. Focusing on corn production in Iowa, we measure how temporary shocks in weather during the corn growing season affect yields. Consistent with a large literature in agronomics, we find that corn is highly sensitive to small changes in temperature, with a few additional hot days during the growing season reducing annual corn yields substantially.

Since local weather affects yields, weather shocks provide exogenous variation in local cash flows and balance sheets during the debt crisis. We exploit this variation in our empirical strategy by relating weather-driven cash flow shocks to a host of real and financial variables - both during the farm debt crisis as well as outside of it. Our analysis focuses on land markets, the propagation of shocks into the financial sector, and on labor markets. While during normal times, firms should be able to smooth temporary shocks, in financial crises and other periods of large financial frictions, such smoothing is difficult as external finance is often prohibitively costly or unavailable. ${ }^{3}$ An inability to smooth shocks during a crisis is predicted, therefore, to translate to a host of market outcomes, both real and financial. Consistent with financial accelerator theories, our results show that cash injections during the crisis positively affect land markets, the financial sector, and labor markets in an economically meaningful manner, and ultimately translate into increases in county per-capita income.

We start by examining the effect of cash-flow driven weather shocks on agricultural land prices. We expect that during a financial crisis, increases in cash available to firms will support asset

\footnotetext{
${ }^{2}$ For an analysis of the farm debt crisis see e.g. Calomiris, Hubbard, and Stock (1986) and Barnett (2000).

${ }^{3}$ Brunnermeier and Sannikov (2014) provide a model consisting of two regimes - crisis and non-crisis - in which, in the former, small shocks are amplified, while in the latter these shocks are absorbed by agents.
} 
prices by mitigating fire sales. When financial frictions are high, asset prices will be affected by cashin-the-market pricing, as economic agents cannot raise external finance to bring prices to fundamental value (Allen and Gale 1994, 1998; Shleifer and Vishny 1992; Kiyotaki and Moore 1997). ${ }^{4}$

Consistent with cash-in-the-market pricing, we show that weather-induced cash flow injections do indeed increase land prices. Since our specifications include both year and county fixed effects, our identification strategy is driven by comparing, within a given year, counties that received differential weather shocks, as compared to their sample mean. We find that counties that received a positive cash flow injection - driven by relatively good weather - exhibit higher land values than counties that receive a negative cash flow shock - driven by a few additional days of high temperature weather during the growing season. Instrumenting for county-level crop yields with our weather shock variable, we find an elasticity of land prices to yields during the farm debt crisis of 0.33 . As a placebo test, we rerun our analysis on the period outside of the farm debt crisis and find no statistically significant relation between land values and weather shocks. To our knowledge, this is the first study that provides causal evidence of cash-in-the-market pricing.

We continue our analysis by examining how cash flow injections propagate into the financial sector. We first show that during the crisis, counties that experience reduced crop yields due to bad weather shocks exhibit higher agricultural loan delinquencies: as would be predicted, farms in these counties find it more difficult to repay their obligations. We then show that county level (weatherdriven) cash injections reduce the probability of bank local bank failure during the crisis. The effect is economically significant, with a 10 percent drop in crop yields increasing the probability of a county

\footnotetext{
4 As in all models of cash-in-the-market pricing, an implicit assumption here is that asset markets are at least partially segmented in that capital cannot flow seamlessly from one market to the other (see e.g. Shleifer and Vishny 1992; Allen and Gale 1994, 1998; Duffie 2010). The market for agricultural land is thought to fit this assumption well, as land is often purchased by neighboring local farms - a hypothesis we confirm below with a hand-gathered, micro-level dataset of land transaction records. See also Chaney, Sraer, and Thesmar (2012) for the impact of changes in real estate prices on corporate investment via a collateral channel.
} 
bank failure by 3.2 percent. ${ }^{5}$ Banks thus appear unable to smooth temporary shocks to their balance sheets during the debt crisis, consistent with the existence of financial constraints and an external finance premium at the bank level. ${ }^{6}$

We then turn to the effect of cash flow injections during crises on labor markets. We begin by focusing on the labor market in the agricultural sector and then examine spillovers into labor markets in other sectors. The results show that counties that experience a negative weather-driven cash flow shock during the crisis exhibit lower agricultural employment rates as well as a reduction in average county agricultural wages, consistent with a reduction in farms' labor demand. ${ }^{7}$ During the debt crisis when financial frictions are high, lower firm cash balances thus translate into labor market disruptions and decreased employment. Alternatively, exogenous cash injections during times of high financial frictions serve to support employment. We rerun the analysis outside of the farm debt crisis, and show that exogenous cash flow shocks do not effect employment and wages during this time period, consistent with firms' greater ability to smooth shocks when financial frictions and the cost of external finance are lower.

We next examine labor market spillover effects of cash flow shocks in the agriculture sector on the service sector. ${ }^{8}$ We hypothesize that during the debt crisis disruptions in agricultural labor markets following cash flow shocks will spill over into other labor markets. This is indeed what we find. During the debt crisis, county-level weather-driven negative cash flow shocks in the agricultural sector are related to employment increases, as well as average wage decreases, in the local service sector.

\footnotetext{
${ }^{5}$ As a placebo test, we rerun the analysis relating cash flow shocks to bank failures and loan delinquencies outside of the crisis. As expected, we find no significant relations.

${ }^{6}$ For an analysis of the implications of bank-level financial constraints see, e.g., Bernanke and Blinder (1988); Kashyap and Stein (2000); and the literature on the bank-lending channel of monetary policy.

7 We confirm that outside of the crisis period, weather driven cash flow shocks have no effect on employment or on average wages in the agricultural sector.

${ }^{8}$ Examining wages and employment in manufacturing, we do not find any significant effects.
} 
During the crisis, a negative cash flow shock in agriculture appears, therefore, to increase labor supply in the service sector, with workers reallocating from agriculture to services.

We continue by examining whether these labor market spillovers in the service sector depend on the share of agriculture in the local economy. Our hypothesis is that when the agriculture sector is large within a given county, reductions in agricultural employment following a negative cash flow shock will reduce local demand, and hence employment, in the service sector. ${ }^{9}$ Running interaction specifications conditioning on the share of agricultural income within the county, we find results consistent with this demand channel: in counties where farming is more dominant, during the farm debt crisis negative cash flow shocks in agriculture have a negative effect on employment within the service sector. Firms' inability to smooth cash flow shocks during the debt crisis is thus transmitted to other industries located within the same area, as employees are dislocated within the economy.

We conclude by analyzing whether and to what extent exogenous cash flow shocks ultimately affected county-level income during the debt crisis. Using local weather shocks to obtain exogenous variation in county level cash flow, we calculate the local-level cash-flow to income multiplier - i.e. the increase in income associated with an exogenous dollar injection of cash flow. The results show that positive cash flow shocks during the debt crisis did indeed increase local income levels, with our estimates pointing to a multiplier of approximately 1.63. In periods outside of the debt crisis, we do not find a statistically significant relation between (weather-driven) cash flow shocks and county income levels. The size of the cash flow to income multiplier is thus state dependent, and larger during crises. $^{10}$

\footnotetext{
${ }^{9}$ See Mian and Sufi (2014) for an examination of the relation between local household demand shocks and employment within the tradable and non-tradable sectors during the 2008-2009 recession.

${ }^{10}$ For a discussion of the difficulty in estimating state-dependent fiscal multipliers, see Parker (2011). Auerbach and Gorodnichenko (2012) use a smooth transition VAR to estimate fiscal multipliers over the business cycle, finding a multiplier of between 1.5 and 2 in recessions. See also Ramey and Zubairy (2014), which employs a long time series of U.S. data to estimate state-dependent fiscal multipliers and Chodorow-Reich et al. (2012) which examines the effect of state-level fiscal policy on employment. Nakamura and Steinsson (2014) estimate government spending multipliers using
} 
Taken together, our results show how cash injections into an economy during a debt crisis can have important effects on a host of real and financial outcomes. When cash balances are reduced, asset prices decline, delinquency rates rise, banks are more likely to fail, labor market disruptions ensue, and income levels decline. Conversely, increased cash balances during the crisis improve conditions in local land markets, financial markets, and labor markets, and ultimately raise income levels. From a policy perspective, our results thus point to the potential value of cash injections during a financial crisis that serve to strengthen firm balance sheets, thereby aiding firms in overcoming frictions in financial markets.

The paper proceeds as follows. The next section presents the empirical strategy, data, and a description of the farm debt crisis, along with the summary statistics. Section 3 presents the empirical analysis: Section 3.1 confirms that weather shocks affect crop yields; Section 3.2 analyzes the effect of weather-driven county-level cash flow shocks on land markets; Section 3.3 focuses on the propagation of cash flow shocks into the banking sector; Section 3.4 analyzes the effect of cash flow shocks on labor markets, focusing on employment and wages; and Section 3.5 investigates the multiplier of cash flow shocks on income-per-capita. Section 4 concludes.

\section{Empirical Methodology and Data}

\subsection{Empirical Strategy}

Our empirical strategy employs idiosyncratic weather shocks and their attendant effect on agricultural growing productivity as a source of variation in local cash flow. An extensive body of literature has shown that variation in weather has a strong effect on agricultural productivity (see, e.g.,

variation driven by military procurement. See also the literature on fiscal policy at the zero lower bound (e.g. Krugman 1998; Eggertsson and Woodford 2003; and Christiano, Eichenbaum, and Rebelo 2011). 
Dell, Jones, and Olken 2014, for a review). This variation is plausibly exogenous to farm-level activity, certainly within the frequency we study.

The analysis focuses on the state of Iowa, which provides an ideal setting for examining the effects of weather on agricultural outcomes. Agricultural production is significant in Iowa and constitutes a large portion of economic activity in the state. ${ }^{11}$ Iowa also ranks first out of all states in production of corn - an important U.S. crop whose response to temperature fluctuations is well understood. Finally, agricultural data for Iowa are available at a more detailed level and for a longer time period compared to other states, allowing for a more complete time series of our empirical tests.

Our main empirical strategy uses an instrumental variable approach to relate exogenous weather-driven changes in crop yields to economic outcomes in various markets of interest: the market for land, the local financial sector, and labor markets. In doing so, we rely on an extensive prior literature in agricultural economics showing that corn is highly sensitive to variation in temperature during the growing season - the months from April through September - with even a few additional days of hot weather significantly reducing annual corn yields (see e.g. Schlenker and Roberts 2006, 2009). Thus, the variation exploited in our identification strategy is not periods of drought or extreme heat throughout the growing season, but rather relatively small variation in temperature across counties within a given year. We measure county-level annual exposure to harmful temperature using the cumulative number of days in the growing season with average daily temperature above 83 degrees Fahrenheit $\left(83^{\circ} \mathrm{F}\right)$, a threshold corresponding to that identified in the literature. ${ }^{12}$ Annual county-level corn yields are instrumented in a first stage regression with the days-above- $83^{\circ} \mathrm{F}$ weather shock

\footnotetext{
${ }^{11}$ According to the Iowa Farm Bureau, the agriculture sector accounts for $\$ 72$ billion in Iowa's economy annually and creates one out of every six new jobs.

12 Schlenker and Roberts (2009) find that hot temperature is harmful to corn yields past a threshold of $28^{\circ} \mathrm{C}$ to $29^{\circ} \mathrm{C}$ (depending on the geographical region), i.e. $82.4^{\circ} \mathrm{F}$ to $84.2^{\circ} \mathrm{F}$. They show that an additional day of weather at $40^{\circ} \mathrm{C}\left(104^{\circ} \mathrm{F}\right)$ instead of $29^{\circ} \mathrm{C}\left(84.2^{\circ} \mathrm{F}\right)$ leads to an approximately $7 \%$ predicted decline in annual yields.
} 
variable - i.e. the number of days in the growing season with temperature above $83^{\circ} \mathrm{F}-$ and in a second stage regression various variables of interest (described below) are related to the instrumented yields. The first-stage regression in our analysis is thus given by:

$$
\log \left(\text { Corn Yield }_{i, t}\right)=\beta_{0}+\beta_{1}\left(\text { Days Above 83) }{ }_{i, t}+\delta_{t}+\gamma_{i}+\varepsilon_{i, t}\right.
$$

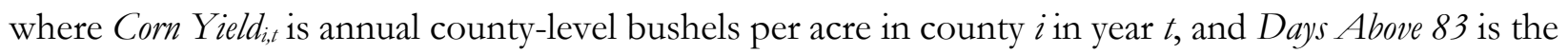
annual number of days in the corn growing season in each county which have an average temperature above $83^{\circ} \mathrm{F}$. Regression (1) is run at the county-year level and includes year fixed effects, $\delta_{t}$, as well as county fixed effects, $\gamma_{i}$, to absorb time-invariant omitted characteristics at the county level as well as shocks common to all counties within a given year. Our second-stage regression specification examines the effect of instrumented corn yields, given by (1), on various outcome variables:

$$
\left.Y_{i, t}=\beta_{0}+\log \widehat{\text { Yield }}_{i, t}\right)+\delta_{t}+\gamma_{i}+\varepsilon_{i, t}
$$

where $Y_{i, t}$ is the outcome variable of interest for county $i$ in year $t, \log \left(\right.$ Yiel $\left._{i, t}\right)$ is predicted $\log$ corn yield as instrumented via regression (1), $\delta_{t}$ are year fixed effects, and $\gamma_{i}$ are county fixed effects. ${ }^{13}$ The outcome variables examined are average agricultural land values, agricultural loan delinquency rates, number of bank failures, average wages, and employment, all at the county-level. The exclusion restriction underlying the identification strategy is that temperature shocks are exogenous and only affect the outcome variables in (2) through their impact on corn yields and farm cash flow. As discussed below, in support of this assumption, using placebo regressions we do not find any effects of weather shocks on the various outcome variables in non-crisis periods when financing frictions are less likely to bind, despite the fact that weather shocks continue to affect yields.

\footnotetext{
13 We cluster standard errors at the year level in order to account for spatial correlation between counties. By doing so, we are assuming that all counties in Iowa are correlated, regardless of their distance to one another - a stronger assumption than a typical spatial correlation adjustment of standard errors (e.g. Conley 1999) which assumes that the correlation decays with distance.
} 
One potential concern in the interpretation of our results stems from farmers' ability to hedge weather shocks by purchasing crop insurance. However, due to the relatively late development of crop insurance in the United States, hedging is of limited concern in our empirical setting. Indeed, while crop insurance markets have been available since the 1930s, they operated on a limited basis until the 1990s, during which time the U.S. government passed a number of laws that greatly expanded the insurance market. ${ }^{14}$ Further, the presence of hedging would bias our effects downward, as any crop insurance or weather-related governmental transfers to the agricultural sector would make farm net worth less sensitive to the effect of weather shocks.

\subsection{Data Sources}

We construct a novel dataset of county-level outcome variables in Iowa using a variety of sources. For our temperature data, we collect daily weather station data for Iowa from the National Oceanic and Atmospheric Administration (NOAA) from 1950 to 2010. Using this daily data, we calculate for each weather station the number of days in the corn growing season (from April $1^{\text {st }}$ to September $30^{\text {th }}$ ) with an average daily temperature above $83^{\circ} \mathrm{F} \cdot{ }^{15}$ We then construct county-level estimates of this temperature measure for Iowa following the procedure in Deschênes and Greenstone (2012): Using geographical data for each county in Iowa from the U.S. Census Bureau, we construct a county-level estimate of the annual number of hot days (i.e. above $83^{\circ} \mathrm{F}$ ) in the growing season by

\footnotetext{
${ }^{14}$ Federally subsidized crop insurance was introduced by the Federal Crop Insurance Act of 1980. However, this law did not result in significant growth in crop insurance participation, which remained very low throughout the 1980s (Glauber 2013; Hart and Babcock 2000). In the 1990s, laws such as the Federal Crop Insurance Reform Act of 1994 provided for greatly expanded governmental subsidies in support of crop insurance and also implemented mandatory catastrophic coverage in order to protect producers against major losses. As a result of this law, as well as other laws passed in the 1990 s, crop insurance coverage rose substantially to more than two thirds of total planted field crop acreage by the end of the decade (see the USDA Risk Management Agency, http://www.rma.usda.gov/aboutrma/what/history.html). It should be noted that a key driver in passing the series of crop insurance laws in the 1990s was the 1980s farm debt crisis itself (see, e.g., Stam and Dixon 2004).

${ }^{15}$ As is common in the literature, in any given year we only use weather stations that have non-missing data for every day in July.
} 
using a weighted average of all weather station estimates within a 50 kilometer radius of the geographical center of each county. The weights used are the inverse of the squared distance from each weather station to the geographical center of the county. As there are 99 counties in Iowa, this process yields a total of 6,032 county-year temperature observations for the sample period 1950-2010, and 693 observations for the crisis period 1981-1987.

Our measure of corn yields comes from the USDA's National Agricultural Statistics Service (NASS) yearly crop surveys. The NASS provides yearly county-level data of average corn yields from 1950 to 2010, measured in bushels per acre harvested. Our measure of farmland values come from the Iowa State University Farmland Value Survey, which provides yearly county-level estimates of the average value per acre of Iowa farmland from 1950 to $2010 .{ }^{16}$ Studies have shown that these survey values closely track actual land sales prices (see e.g. Stinn and Duffy 2012; and Kuethe and Ifft 2013).

We use two different data sources to examine the effect of weather-driven shocks on banks. The first source is data on agricultural loan delinquencies from the Federal Reserve's Commercial Bank Data Call Reports. Delinquent loans are defined at the bank level as the outstanding balance of agricultural loans that are 90 days or more past-due and upon which the bank continues to accrue interest (these data are available from 1984 to 2000). For each county in Iowa, we aggregate delinquent balances of all banks headquartered in that county, to obtain a county-level measure of delinquent agricultural loans. ${ }^{17}$ In addition, we use data on bank failures for each county taken from the Federal Deposit Insurance Corporation (FDIC). These data run from 1950 to 2010. In order to properly attribute the effects of temperature shocks during the growing season to subsequent bank failures, we

\footnotetext{
16 A potential concern with the estimates of farmland value is that some parcels of land may be irrigated (thus leading to a higher value) while others may not. However, very little of the farmland in Iowa is irrigated, implying that this is not a concern for our sample. For example, according to data from the U.S. Agricultural Census and the NASS, only $2.6 \%$ of total Iowa farmland was irrigated in 2012.

${ }^{17}$ Note that Call Report data do not provide information by borrower location. However, since most banks headquartered in Iowa are relatively small, loans by these banks are generally originated to borrowers located in the vicinity of bank headquarters.
} 
mark a bank failure as occurring in year $t$ if it occurred within the period from the end of the growing season in year $t$ (October and onwards) through the growing season of year $t+1$.

Our final data source is the Quarterly Census of Employment and Wages taken from the Bureau of Labor Statistics. We collect data on county-level employment, average annual wages, and total county-level wages. The data are available for the period 1975-2000. The agricultural crop production sector is defined as SIC code 01. In addition, we use the services sector (SIC division 0I) and manufacturing sector (SIC division 0D). A caveat with our agricultural wage and employment data is that the Quarterly Census of Employment and Wages only covers larger farms - it does not cover most agricultural workers in small farms or self-employed agricultural workers. ${ }^{18}$

\subsection{The Farm Debt Crisis}

The period preceding the 1980s farm debt crisis exhibited sharp increases in debt levels and land values, as common in many financial crises. ${ }^{19}$ During the 1970 s, increasing commodity prices along with an expansion in demand for U.S. exports of agricultural commodities led to increased farm production and greater investment in farmland. Between 1971 and 1980, agricultural exports roughly doubled, the real price of commodities such as corn increased by over 35 percent, while farmland values rose by 88 percent (see Calomiris, Hubbard, and Stock 1986). During this period of land price appreciation, leverage played an increased role in the financing of agricultural land purchases. ${ }^{20}$ For example, whereas in 1950, 42 percent of all agricultural land transactions occurred with no debt financing, by 1978 only 11 percent of transactions occurred without relying on debt capital. The

\footnotetext{
18 In particular, the Quarterly Census of Employment and Wages data do not include farms which consistently employed fewer than 10 individuals in agricultural labor or which paid less than $\$ 20,000$ in total cash wages to individuals employed in agricultural labor during the current or preceding calendar year.

${ }^{19}$ For a historical survey of the 1980s farm debt crisis, see Harl (1990) and Barnett (2000).

${ }^{20}$ See FDIC Division of Research and Statistics (1997).
} 
increased reliance on debt, coupled with rising farmland prices, led to a 66 percent increase in aggregate farm debt levels over the period 1971-1980 (Calomiris, Hubbard, and Stock 1986).

The farm debt crisis is generally thought to have been triggered in the early 1980 s by the combination of several factors. The first was a tightening of monetary policy undertaken by the Federal Reserve in 1979 under Paul Volcker, which increased interest rates and raised the burden of farmer debt repayment. The interest rate increase also contributed to a strengthening of the U.S. dollar, making U.S. agricultural exports less competitive in the global market. Finally, the U.S. implemented a ban on grain exports to the Soviet Union in 1980, which contributed to a further decline in exports. As a result of these factors, many farmers who had invested heavily in production over the previous decade, often increasing their leverage in the process, faced a sudden reduction in demand for agricultural commodities coupled with a large increase in the cost of borrowing. The result was a period of severe financial distress and deleveraging in the agricultural sector with significant drops in farm income, sharp declines in farmland values, impaired farm balance sheets, and an erosion in farm credit conditions.

From 1981 to 1987, the average value of farmland dropped by 50 percent across corn-belt states (Barnett 2000). Nationwide, non-performing loans at agricultural banks rose from 2.8 percent of total loans in 1982 to 6.7 percent in 1986, and 100 small agricultural banks failed in 1984 and 1985 alone (see Calomiris, Hubbard, and Stock 1986; and FDIC Division of Research and Statistics 1997). The farming sector saw significant deleveraging with total real agricultural debt declining by 37 percent from 1981 to 1987. In Iowa, real farmland prices dropped by an average of 67 percent across all counties between 1981 and 1987, with 39 commercial bank failures in that period. Furthermore, the majority of bank failures - 34 of the 39 - occurred between 1984 to 1987, considered to be the peak of the crisis. 


\subsection{Summary Statistics}

Table 1 presents summary statistics of the main variables. Panel A provides summary statistics for the debt crisis period defined from 1981 to 1987, while Panel B provides summary statistics for the height of the crisis from 1984 to 1987 . For comparison, Panel C provides summary statistics for the non-crisis period.

During the crisis years of 1981 to 1987 , the average number of days in the growing season with an average temperature exceeding $83^{\circ} \mathrm{F}$ is 3.25 , while the average number of days above $83^{\circ} \mathrm{F}$ outside of the crisis is 2.51 . As would be expected, the average annual number of days above $83^{\circ} \mathrm{F}$ during the growing season does not differ substantially in the crisis period as compared to the noncrisis period. ${ }^{21}$ Figure 1 reports density plots of the distribution of days above $83^{\circ} \mathrm{F}$ over our entire sample. As can be seen from the figure, roughly 45 percent of the county-year observations have one or fewer days with an average temperature above $83^{\circ} \mathrm{F}$, while the density function is monotonically decreasing. As our main specifications include county and year fixed effects, Figure 1 exhibits variation which we do not exploit in our identification strategy. Figure 2, therefore, presents density plots of temperature variation demeaned with year and county fixed effects. The distribution of demeaned days above $83^{\circ} \mathrm{F}$ appears symmetric around zero, but also exhibits substantial variation. Density plots for individual years (Figure 3) in the crisis and non-crisis period indicate substantial variability across counties for any given year, with some years exhibiting a significantly higher number of days above $83^{\circ} \mathrm{F}$.

As can further be seen in Table 1, corn yields range from 105.7 to 123.8 bushels per acre. The mean land value during the $1981-1987$ period is $\$ 2,947$ per acre and is $\$ 1,978$ per acre during the 19841987 period (all in real 2010 dollars). Finally, agricultural loan delinquencies are higher during the crisis,

${ }^{21}$ A comparison of means is unable to reject equality. 
as would be expected. Figure 4 depicts the evolution of average corn yield, land value, and agricultural debt across all counties during the sample. Average corn yields increase over the sample period, while land values increase gradually from 1950 to 1970 , and then substantially from 1970 to 1980 . In the early 1980s, corresponding to the period of the farm debt crisis, land values drop precipitously. By contrast, corn yields do not exhibit such a trend during the debt crisis. Finally, agricultural debt increases steadily from 1960 to 1980 but drops significantly during the farm debt crisis, as would be expected by a deleveraging process common in financial crises.

\section{Empirical Results}

As explained in Section 2, we analyze the effect of cash flow injections during a debt crisis by exploiting variation in weather shocks across counties and over time in Iowa. These weather shocks, and the associated effect on corn yields, provide an exogenous source of variation in cash flow, and hence farm balance sheets, during the crisis. We begin by confirming that county-level weather variation is indeed related to farm yields in our data.

\subsection{Weather Shocks and Crop Yields}

As described above, to measure weather shocks we construct a variable, Days Above 83, defined at the county-year level, which equals the number of days during the growing season where the average daily temperature within the county was above $83^{\circ} \mathrm{F}$. This temperature threshold is taken from Schlenker and Roberts (2009), although our results are robust to alternate definitions of high temperature values.

We confirm in our data the relation between yield and weather shocks found in the agronomics literature by running the following reduced-form specification: 


$$
\log \left(Y_{i, t}\right)=\beta_{0}+\beta_{1}(\text { Days Above 83) })_{i, t}+\delta_{t}+\gamma_{i}+\varepsilon_{i, t}
$$

$Y_{i, t}$ is corn yields (bushels of corn produced per acre) in county $i$ in year $t$, and Days Above 83 is the weather shock variable capturing hot average-temperature years. Regressions include a vector of year fixed effects $\left(\delta_{t}\right)$ and a vector of county fixed effects $\left(\gamma_{i}\right)$. A potential concern with the regression above is that the error terms may be correlated across nearby geographical regions. To address this, we follow the literature in agronomics (e.g. Deschênes and Greenstone 2007; Schlenker and Roberts 2006, 2009) and calculate standard errors correcting for spatial correlation as in Conley (2008).

Table 2 reports the results of regression (3) over the farm debt crisis sample period of 1981 to 1987. Employing year, but not county, fixed effects, Column 1 shows that high temperature is indeed detrimental to corn yields. Column 2 shows that adding county fixed effects does not substantially change the results. As the coefficient on the weather shock variable, Days Above 83, shows, adding an extra day during the growing season with an average temperature above $83^{\circ} \mathrm{F}$ reduces annual corn yields by 3.3 percent. While seemingly high, this result is consistent with much prior work in the agronomics literature, such as Schlenker and Roberts (2009). Corn is extremely sensitive to high temperature values during the growing season - an established fact that lies at the heart of our identification strategy.

In Column 3, we report the results for the period of 1984 to 1987 - the peak of the farm debt crisis - and find similar results. In Column 4 we estimate the results for the non-crisis period. The effect of weather on yields is biological and hence, as expected, the estimated coefficient on the weather shock variable during the non-crisis period (Colum 4) is similar to those during the crisis period (Columns 1-3). 


\subsection{Cash Flow Shocks and Asset Prices}

Having confirmed the effect of temperature on yields, we analyze how temperature shocks, and the variation they induce in farm cash flows, affect local land prices. Following cash-in-the-market pricing theories (Shleifer and Vishny 1992; Allen and Gale 1994; and Kiyotaki and Moore 1997), we hypothesize that during debt crises, when financial frictions and the cost of external finance are high, counties that receive negative cash flow shocks stemming from weather variation will exhibit lower agricultural land prices: negative weather shocks reduce the net worth of local buyers - i.e. nearby farmers - who will thus have less funds to purchase land.

As in all models of cash-in-the-market pricing, an implicit assumption required for land prices to be affected by local liquidity conditions is that the market for land is at least partially segmented, in that capital cannot flow seamlessly from afar (see, e.g., Shleifer and Vishny 1992; Allen and Gale 1994, 1998; Duffie 2010). This assumption is likely satisfied in the market for agricultural land, which is generally thought to be highly localized. However, to confirm this assumption, we hand-collect a micro-level dataset on land transactions within one county in Iowa - Hamilton county - between the years 1970 and $1988 .{ }^{22}$ For each of the 1,971 sales of agricultural land in Hamilton county, we mark the county of the buyer and calculate the monthly fraction of out-of-county buyers. As can be seen in Figure 5, the data confirm that agricultural land sales are highly localized: only 9.4 percent of transactions occur with an out-of-county buyer. Interestingly, the fraction of out of county buyers increases substantially during the financial crisis, reaching 25 percent in 1985. This spike in out-ofcounty purchases is very much consistent with, and in fact would be predicted by, the existence of fire sales, in which capital from afar flows into the market to buy liquidated assets.

Having confirmed that agricultural land markets are localized, we examine the effect of exogenous county-level weather-induced cash flow shocks on the price of land during the crisis. Table

\footnotetext{
22 The data are hand-collected from the Hamilton county courthouse where they are located in non-electronic form.
} 
3 reruns the reduced form specification in regression (3) but employs $\log ($ Land $V$ alue $)$, the average county-level price per acre of farmland (in 2010 dollars), as the dependent variable. Consistent with the prediction of cash-in-the-market pricing, we find that counties that received a positive cash flow injection - driven by relatively good weather - exhibit higher land values than counties that receive a negative cash flow shock - driven by a few additional days of high temperature weather during the growing season. ${ }^{23}$ Focusing on Column 2, which includes county fixed effects, an additional day during the growing season with an average temperature greater than $83^{\circ} \mathrm{F}$ reduces average price per acre by 0.4 percent. In Column 3, which reports the results for the period during the peak of the farm debt crisis, 1984-1987, the estimated magnitudes are even larger: during the growing season, an additional day with average temperature exceeding $83^{\circ} \mathrm{F}$ reduces land values by 0.7 percent. To our knowledge, this is the first study that provides causal evidence of cash-in-the-market pricing.

To provide intuition as to why land prices move following a negative weather shock, it is instructive to conduct a back-of-the-envelope estimate of the effect of weather variation on farm balance sheets. First, it should be noted that farming involves relatively low profit margins - on the order of 6 percent. ${ }^{24}$ Consider then a shock that adds an extra day of high temperature, i.e. with average temperature above $83^{\circ} \mathrm{F}$, during the growing season. Based on our estimates above, and consistent with prior literature, this incremental hot day reduces average annual yield by 3.3 percent. Assuming that costs are unaffected by the bad weather shock (in fact, costs tend to rise following such a shock) annual profits are expected to decline by approximately 50 percent. ${ }^{25}$ Due to small profit margins, variation in weather can have a large influence on farm cash positions - a standard operating leverage

\footnotetext{
23 To reiterate, a reduction in the weather shock variable, Days Above 83, captures exogenous positive cash flow injections into a county.

${ }^{24}$ See Hoppe and Banker (2006).

${ }^{25}$ With a 6 percent profit margin, $P=0.06 \times \mathrm{R}$ and $\mathrm{C}=0.94 \times \mathrm{R}$, where $P, \mathrm{R}$, and $C$ are profit, revenue, and cost, respectively. Since the weather shock reduces revenue by 3.3 percent, the resultant profit - i.e. post-weather shock - will be $0.027 \mathrm{R}$ rather than $0.06 \mathrm{R}$. Profit thus declines by approximately fifty percent.
} 
effect - which then feeds into land prices as shown in Table 3.

The results in Table 3 regarding the relation between weather shocks and land prices focuses on the farm debt crisis period. At the center of the theoretical argument behind this result is the assumption that financial frictions prevent firms from raising external financing to smooth shocks or make it prohibitively costly for them to do so. According to this argument, we thus expect that outside of the crisis, the effect of weather shocks on land prices is greatly diminished (or non-existent), even while these shocks continue to affect yields and hence cash flows. Column 4 conducts this test by considering the impact of exogenous weather shocks outside of the 1980s farm debt crisis. As can be seen, in contrast to the results in Columns 1-3 of Table 3, weather variation outside of the crisis years has no statistically significant relationship with land prices, consistent with an increased ability of firms to smooth cash flow shocks. Thus, even though negative weather shocks continue to detrimentally affect yields outside of the crisis (see Table 2, Column 4), they have no effect on land values outside the $_{\text {crisis. }}{ }^{26}$

Table 3 provides a reduced form estimation of the relation between weather shocks and land values. To estimate the elasticity of land values to exogenous variation in yields during the debt crisis, we employ the following instrumental variable approach. The first stage instruments for yields using exogenous weather shocks, as in regression (1) above, while the second stage relates county average land values to the predicted yields taken from the first stage. Specifically, we run:

$$
\left.\log \left(\text { Land Value }_{i, t}\right)=\beta_{0}+\log \widehat{(\text { Yield }}_{i, t}\right)+\delta_{t}+\gamma_{i}+\varepsilon_{i, t} \text {, }
$$

\footnotetext{
${ }^{26}$ One concern regarding the relation between land values and weather-driven cash flow shocks is that potential buyers might mistakenly believe that temporary weather shocks are indicative of longer-term shifts in weather activity. This, for example, could arise due to a behavioral bias by which, following a negative weather shock, potential land buyers overestimate the conditional probability of future negative weather shocks. However, this expectation-driven explanation is not consistent with the fact that land values exhibit no relation with weather shocks outside of the crisis.
} 
where $\log \left(\right.$ Yiel $\left._{i, t}\right)$ is instrumented $\log$ corn yield in county $i$ in year testimated via (1), and Land Value $e_{i, t}$ is the average land value (in 2010 dollars per acre) of county $i$ in year $t$. As in all specifications, $\delta_{t}$, represents a vector of year fixed effects, and $\gamma_{i}$ represents a vector of county fixed effects.

The results are shown in Table 4. Column 1 of the table provides the first-stage estimation. Column 2 of the table exhibits the results of the second stage, finding an elasticity of land values to yields of 0.114 - a 10 percent exogenous increase in county yields is thus associated with a 1.14 percent increase in land values during the debt crisis. Columns 3 and 4 conduct the instrumental variable strategy starting from 1984 - the height of the crisis years - and up to its end in 1987. Consistent with higher financial constraints during the height of the crisis, the second stage elasticity of land prices to yields is 0.33 , or roughly three times larger than the effect during the full crisis period.

\subsection{Cash Flow Shocks and the Financial Sector: Delinquencies and Bank Failures}

Having shown how weather shocks affect yields and land prices, in this section we analyze how temporary shocks to cash flow during the debt crisis propagated into the financial sector. In the presence of financial frictions, negative weather shocks are expected to reduce farms' ability to repay loans. Cash flow shocks in the real sector will thus transmit into balance sheet shocks in the financial sector. If financial constraints amongst banks during the crisis are sufficiently severe, raising external capital to smooth temporary shocks will be difficult, leading to increased bank failure rates. ${ }^{27}$ Cash injections and the strength of firm balance sheets in the real sector can therefore impact and spill over into the financial sector.

To analyze the propagation of shocks from the real sector to the financial sector during a debt crisis, we first verify that negative cash flow shocks do indeed translate into higher delinquencies on

\footnotetext{
${ }^{27}$ For the importance of bank-level financial constraints, see, e.g., Bernanke and Blinder (1988); Kashyap and Stein (2000); and Bernanke and Gertler (1995).
} 
agricultural loans during the crisis. For each county-year we calculate the aggregate outstanding balance of agricultural loans that are 90 days or more past due. Data on agricultural loan delinquencies are taken from the Federal Reserve Call Reports. As in the prior section, we employ an instrumental variable approach that runs a first-stage regression in which county average corn yields are instrumented with Days Above 83, the weather shock variable. The second stage then relates countylevel aggregate balance of delinquent loans to county average yields. ${ }^{28}$ Specifically we run:

$$
\left.\log \left(\text { Ag Delinquencies }_{i, t}\right)=\beta_{0}+\log {\overline{\left(\text { Yield }_{i, t}\right.}}\right)+\delta_{t}+\gamma_{i}+\varepsilon_{i, t} \text {, }
$$

where, as in prior regressions, $\log \left(\overline{(Y i e l}_{i, t}\right)$ is instrumented $\log$ corn yield in county $i$ in year $t$ estimated via (1), $\delta_{t}$, represents a vector of year fixed effects, $\gamma_{i}$ represents a vector of county fixed effects, and Ag Delinquencies is the total outstanding balance of delinquent agricultural loans.

Panel A of Table 5 presents the results. As can be seen in Column 1 of the table, delinquency levels vary negatively with yields. The results imply an elasticity of 3 between county aggregate delinquent loans and county average yields: during the crisis, counties which experience a 10 percent weather-driven exogenous increase in yields (as compared to their mean) exhibit a 30 percent decrease in aggregate delinquency rates. As would be predicted, exogenous positive cash injections translated into reduced delinquencies among borrowers.

Loan delinquencies represent, of course, shocks to bank balance sheets. As a next step, we examine to what extent exogenous variation in loan delinquencies transmit into the local financial sector in the form of subsequent county bank failures. We employ our standard instrumental variable approach, first instrumenting county average yields with the weather shocks, and then relating the instrumented yields to bank failure rates at the county-level. Specifically we run the following instrumental variable linear probability model:

\footnotetext{
${ }^{28}$ See Column 3 of Table 2 for the first stage results.
} 


$$
\text { Bank Failure } \left._{i, t}=\beta_{0}+\log {\widehat{\left(\text { Yield }_{i, t}\right.}}\right)+\delta_{t}+\gamma_{i}+\varepsilon_{i, t} \text {, }
$$

where Bank Failure $_{i, t}$ takes on the value of one if there was a bank failure in county $i$ in the period following the growing season in year $t$ up to the end of the growing season in the following year, and zero otherwise. As usual, $\log \left(\widehat{(Y i e l}_{i, t}\right)$ is instrumented $\log$ corn yield in county $i$ in year $t$ estimated via (1), $\delta_{t}$ is a vector of year fixed effects, and $\gamma_{i}$ is a vector of county fixed effects.

Column 2 of Table 5A presents the results. As the table shows, a 10 percent increase in yields leads to an approximately 3.2 percentage point increase in the probability of bank failure. The effect is economically sizeable, as 28 percent of the county-year observations during the period of 1984 to 1987 exhibit a bank failure. Consistent with the hypothesis, temporary cash flow variation driven by exogenous weather shocks did indeed lead to spillovers into the financial sector in the form of bank failures.

Column 3 of the table repeats the analysis, but allows a lag in the time to bank failure. Specifically, we define an indicator variable, Bank Failure Crisis, that takes on the value of one if there was a bank failure from the given year until the end of the crisis (i.e. to 1987), and zero otherwise. As can be seen, the effect of predicted yields on bank failures rises when a time lag to failure is accounted for, with a coefficient in the level-log specification that is approximately -0.4 .

As a placebo test, Panel B of Table 5 examines the effect of temporary cash flow shocks outside of the debt crisis. Lower financial frictions and stronger balance sheets during this period would predict muted effects. This is indeed what the results indicate. As can be seen in Column 1 and Column 2 of Table 5B, cash flow shocks outside of the crisis are not related to delinquency rates or bank failure rates in a statistically significant manner. 


\subsection{Cash Flow Shocks and Labor Markets: Employment and Wages}

We continue by analyzing the effect of temporary cash flow shocks during the crisis on local employment and wages, focusing first on the agricultural sector itself. Panel A of Table 6 focuses on the debt crisis years, examining the relation between weather-driven variation in yields and labor markets outcomes within the agricultural sector. We analyze county average pay and county employment levels, as obtained from the Quarterly Census of Employment and Wages. All regressions employ the instrumental variable approach, whereby county average yields are instrumented first with the weather shock variable, and then predicted yields are related to either wages or employment. Specifically, we run:

$$
Y_{i, t}=\beta_{0}+\log \widehat{\left(\text { Yield }_{i, t}\right)}+\delta_{t}+\gamma_{i}+\varepsilon_{i, t}
$$

where $Y_{\text {it }}$ is a county-level labor-market outcome, and $\log \left(\overline{\text { Yiel }}_{i, t}\right)$ is instrumented $\log$ corn yield in county $i$ in year $t$ estimated via regression (1). We examine three labor-market outcomes: total countylevel wages in the agricultural crop sector ( $A g$ Total Wages), average county-level annual wage for an employee in agricultural crop production ( $A g A v g$ Wages), and total county-level employment in agricultural crop production ( $\mathrm{Ag}$ Employment).

Column 1 of Table 6A exhibits results using total county-level employment as the dependent variable. ${ }^{29}$ As can be seen, there is a positive relation between yields and total county employment. Estimating the economic magnitude of the effect, a one percent drop in yields reduces agricultural employment by 4.3 percent of the sample mean. Thus, during the crisis, farms in counties that received a positive cash flow injection (driven by relatively good weather) reduce their total agriculture employment by less than those that received a negative cash flow shock. Consistent with increased

\footnotetext{
${ }^{29}$ Note that the data from QCEW does not include information for small farms. As small firms are generally thought to be more financially constrained (see, e.g., Gertler and Gilchrist 1994; Beck, Demirgü-Kunt, and Maksimovic 2005; and Hadlock and Pierce 2010), this suggests that the results here underestimate the true relation between yields and labor market outcomes.
} 
financial frictions during the crisis, temporary shocks to firm balance sheets affect employment rates. When financial constraints bind and external capital is costly, labor demand can be influenced by firm net worth.

Continuing with labor market outcomes, Column 2 of Table $6 \mathrm{~A}$ replaces employment with average county wages per employee as the dependent variable. As can be seen, predicted crop yields are positively related to average wages per employee. Counties that experienced a negative weatherinduced cash flow shock exhibit a relative decline in average wages per employee, consistent with a drop in labor demand stemming from reduced ability to finance employee wages out of internal capital. The elasticity of yields to average county pay is 2.9: a one percent reduction in yields is associated with approximately a three percent relative reduction in average wage per employee. Column 3 analyzes total county wages, which combines variation in total county employment as well as variation in county average wage per employee. Unsurprisingly, given the results in the prior two columns, we find that weather driven cash flow injections are positively related to total county wages.

Panel B of Table 6 repeats the analysis but focuses on the period outside of the farm debt crisis. Outside of financial crises, firms' ability to smooth temporary cash flow shocks is greatly enhanced, and so we expect the relation between employment and predicted yields to be dampened. Consistent with this, the results show that outside of the debt crisis, county level employment, average wage per employee, and total wages are unrelated to exogenous (weather-driven) variation in yields. While the strength of a firm's balance sheet, and variation in it, plays a role in determining labor market outcomes during periods of high financial constraints, they play no role outside of the crisis. The results thus suggest that cash injections into the real sector affect labor market outcomes during a debt crisis, but not outside of it.

Table 7 continues by analyzing how cash flow shocks spill over into other labor markets during the debt crisis. Specifically, we use the instrumental variable strategy from above to relate variation in 
predicted yields to local level employment and wages in the service sector - a natural sector where employees dislocated from farming might seek employment. ${ }^{30}$ Column 1 of Table 7A shows that total county-level employment in the service sector is negatively related to weather-driven cash flow shocks in the agricultural sector: when a county is hit with a negative cash flow shock in the agricultural sector, the data show that agricultural employment declines while employment in services rises (compared to the mean county level). Following a negative cash flow shock, workers thus appear to shift from the adversely affected agricultural sector towards other industries. The results in Column 1 of the table show that a one percent reduction in county predicted yields is associated with a 0.34 percent increase in county-level service sector employment.

Still focusing on the debt crisis period, Column 2 of Table 7 examines how average wages in the service sector relate to cash flow shocks in the agricultural sector. Consistent with an outward shift in the supply of workers in services, the coefficient on predicted yields shows that counties that experienced an exogenous negative (weather-driven) cash flow shock in agriculture exhibit a relative decline in wages in the service sector. As workers shift from agriculture to services, labor supply rises and, correspondingly, wages in the sector decline. The elasticity of average county wages in the service sector to county yields is 0.075 - i.e., a ten percent decline in agricultural yields translates into a 0.75 percent drop in service sector wage.

Column 3 of the table examines total county wages in the service sector and finds that these are unrelated in a statistically significant manner to yields. This is not altogether surprising, as the effect on wages and employment run in opposite directions following a negative shock to yields: while average wages in the service sector falls, county employment in the sector rises.

Taken together, the results in Panel A of Table 7 paint a picture by which, during a debt crisis,

\footnotetext{
30 We note that we find no statistically significant adjustments in manufacturing employment in response to weather-driven dislocation in the agricultural sector. Data are taken from QCEW as discussed earlier.
} 
firms' inability to smooth shocks in one sector create externalities in other sectors within the labor market. Workers shift away from firms hit by temporary cash flow shocks, increasing the supply of labor in other sectors. The result is higher employment and lower wages in sectors unrelated to the original cash flow shock.

For completeness, Panel B of Table 7 conducts a placebo test and reruns the specifications of Panel A focusing on the period outside of the crisis. As was shown in Panel B of Table 6, outside of the crisis weather shocks do not affect agricultural employment. Because the agriculture sector is able to smooth cash flow shocks, we expect to find no effect on labor outcomes in the services sector outside of the crisis. This is indeed what the results show. Using the instrumental variable specification outside of the crisis, none of the service sector labor market outcomes are related in a statistically significant manner to (predicted) county level yields.

We next test a second channel - related to shifts in demand - through which cash flow shocks during a financial crisis can spill over into other sectors. The results in Table 6 show how sectoral cash flow shocks during a financial crisis translate into labor market dislocation within the agriculture sector, as firms find it difficult to utilize capital markets to smooth temporary funding shortages. Accordingly, we test the following demand channel for inter-sector spillovers during financial crises: once a given sector is hit by a cash flow shock, firms in the sector cut employment, causing dislocated employees to reduce overall consumption. The shock to the first sector thus propagates into other sectors, which, faced with a reduction in demand, cut employment in their respective sectors. ${ }^{31}$

To test this mechanism, we run similar regressions to those in Table 7 relating employment and wages in the service sector to weather-induced cash flow shocks in agriculture, but interact the weather-driven cash flow shocks with a measure of the importance of agriculture within each county.

\footnotetext{
31 Examining a demand channel, Mian et al. (2013) analyze how local-level shocks to household balance sheets driven by the 2006-2009 collapse in housing prices affect household consumption, while Mian and Sufi (2014) analyze how this household balance sheet shock reduced employment during the 2008-2009 crisis.
} 
Weather shocks are measured, as usual, using the number of growing season days with average temperature above $83^{\circ} \mathrm{F}$, while the importance of agriculture within each county is measured by the ratio of farm crop income to total income within each county. We predict that in counties with a dominant agriculture sector, negative (weather-driven) cash flow shocks will lead to greater declines in overall demand, which will tend to reduce employment in the service sector. This demand-driven effect goes in the opposite direction to the reallocation effect analyzed above whereby workers from agriculture move into other sectors following a cash flow shock in the agriculture sector.

Column 1 of Table 8A presents the results of the interaction specification, analyzing the effect of weather-driven cash flow shocks on service sector employment. As can be seen, the coefficient on the non-interacted weather shock is positive, but the coefficient on the interaction term between the weather shock and the county-level agricultural importance is negative. Thus, as in Table 7 above, in counties where farming plays a relatively small role, negative cash flow shocks in agriculture tends to increase employment in services_-a reallocation channel. However, if agriculture plays a sufficiently large role in a county, cash flow shocks in the agriculture sector reduce employment in services. At the $25^{\text {th }}$ percentile of agricultural importance within the county (captured by the ratio of farm crop income to total income), an additional hot day with temperature above $83^{\circ} \mathrm{F}$ increases service sector employment by 1.3 percent of the sample mean, but in contrast, at the $75^{\text {th }}$ percentile of agricultural importance such a weather shock reduces service sector employment by 0.8 percent. Thus, during a debt-crisis, aggregate county-level cash flow shocks in one sector impose employment externalities on other sectors operating within the same geography. The sign of these externalities depends on the relative importance within the economy of the sector receiving the shock.

Column 2 of Table $8 \mathrm{~A}$ repeats the analysis but analyzes the impact on service sector wages (rather than employment). We predict that detrimental weather-driven cash flow shocks reduce wages and that this effect will be greater when agriculture plays a larger role within a county. However, as 
can be seen in the table, while the non-interacted coefficient on weather shocks does indeed predict a reduction in wages following a negative cash flow shock, the coefficient on the interaction term with the fraction of county-level farm income is not statistically significant.

Panel B of Table 8 repeats the interaction specification in Panel A of the table, but uses the instrumental variable strategy relating labor market outcome variables to predicted log yields (as in Table 7 above). To this end, we separate the sample into two based on median county-level farm importance, and rerun instrumental variable specifications for below median and above median farm importance counties. ${ }^{32}$ The results are consistent with those in Table 7. Employment in services is positively related to predicted yields in counties with above-median farming importance but is negatively related to predicted yields in counties with below-median farming importance. Negative weather-driven cash flow shocks thus decrease employment in services amongst counties where farming plays a large role - consistent with a demand-channel effect - but increases employment in counties where farming plays a relatively smaller role - consistent with a reallocation effect. Further, as can be seen from Columns 3 and 4 of Table $8 \mathrm{~B}$, wages are positively related to predicted yields, although the effect is not statistically significant in above-median farming importance counties.

\subsection{Cash Flow Shocks and Income Per Capita: The Income Multiplier During the 1980s Farm Debt Crisis}

The results of the prior sections show how county-level cash flow shocks during the debt crisis had a sizeable effect on a host of real outcomes across a number of markets. These include the market for land, labor markets, and the local banking sector. A natural question to ask, then, is whether and to what extent exogenous cash flow shocks ultimately affect county-level income during the debt crisis. To investigate this question, we use our standard instrumental variable approach regressing the

\footnotetext{
32 The median ratio of farm income to total county income is 0.226 .
} 
log of county income per capita on the log of county-level yields, with yields instrumented by the exogenous weather shock variable Days Above 83.

The results are presented in Table 9. As can be seen, during the farm debt crisis, instrumented yields are positively related to income per capita, with an elasticity of 0.138 . In contrast, the point coefficient on predicted yields outside of the farm debt crisis period is approximately one third smaller and not statistically significant.

It is instructive to use the results in Table 9 to conduct a back-of-the-envelope calculation of the local-level cash flow to income multiplier - i.e., the increase in county-level income associated with an exogenous dollar injection of cash flow. Based on the elasticity of 0.138 in Table 9, a ten percent weather-driven drop in yields during the crisis is associated with a 1.38 percent drop in county income per capita. This 1.38 percent drop is equivalent to a per-capita reduction of $\$ 356.8$ from the average county-level income-per-capita during the crisis $(\$ 25,855$ in 2010 real dollars). Since the 10 percent drop in yields is equivalent to a reduction of $\$ 219.55$ in county per capita corn sales, our results indicate that during the debt crisis, the multiplier between the exogenous county level cash flow shock and county-level income is $\$ 356.80 / \$ 219.55=1.63 .{ }^{33}$ Based on these estimates, cash flow injections had a significant impact on local economic income during the crisis. ${ }^{34}$

As a consistency check, the county-level income-to-cash-flow shock multiplier can also be calculated employing the reduced form specification relating yields to the number of high temperature days during the growing season. As can be seen in Column 3 of Table 9, an additional growing season day with temperature above $83^{\circ} \mathrm{F}$ leads to a 0.3 percent reduction in income per capita, or equivalently,

\footnotetext{
${ }^{33}$ To calculate the effect of a 10 percent drop in yields on county corn sales, note that the average yield during the crisis was 123.8 bushels per acre while the average real price of corn was $\$ 4.10$ per bushel. The 10 percent drop in yields is thus equivalent to a $12.38 \times 4.10=\$ 50.76$ drop in sales per acre. The average acreage of grown corn per county was 122,854 while the average county population was 28,402 . This implies that a 10 percent drop in yields was associated with a $\$ 219.55$ $(=\$ 50.76 \times 122,854 / 28,402)$ drop in county per capita sales.

34 As Table 9 shows, outside of the debt crisis, the point estimate of the income-per-capita to yield elasticity is 0.34 with a 95 percent confidence interval of -0.26 to 0.94 .
} 
a reduction of $\$ 77.57$ as compared to the mean income per capita of $\$ 25,855$ during the crisis. From Table 2, an additional growing season day with temperature above $83^{\circ} \mathrm{F}$ leads to a 2.2 percent drop in corn yields during the crisis, which in turn is equivalent to a $\$ 48.30$ (in 2010 real dollars) drop in county per capita sales. ${ }^{35}$ The multiplier between the exogenous cash flow shock and county-level income is thus $\$ 77.57 / \$ 48.30=1.61$, which is similar to the 1.63 estimate obtained above.

\section{Conclusion}

In this paper, we examine the general equilibrium effects of cash flow injections during a financial crisis. Analyzing the 1980s farm debt crisis, our empirical strategy exploits random weather shocks as a source of exogenous cash flow variation. Our analysis tracks the effect of weather induced cash flow shocks during the crisis on a host of outcomes in the real and financial sector. We find that exogenous cash flow shocks during the crisis have significant effects on land values, loan delinquency and bank failure rates, as well as on employment and wages.

Consistent with cash-in-the-market pricing, during the debt crisis, farms in counties that received a positive cash flow injection - driven by relatively good weather - exhibit higher land values than those that received a negative cash flow shock. Placebo regressions show that the cash-in-themarket pricing effect does not arise outside of the debt crisis when financial frictions are expected to be lower.

Examining the financial sector, we show that exogenous shocks to the real sector propagate into the financial sector during the debt crisis: counties that receive negative cash flow shocks exhibit higher delinquency rates on loans as well as more bank failures. Consistent with financial constraints

35 With an average real price of corn of $\$ 4.10$ per bushel and an average yield of 123.8 bushels per acre during the crisis, a 2.2 percent drop in corn yields leads to a drop of $\$ 4.1 \times 123.8 \times 0.022=\$ 11.17$ in sales per acre. Given an average acreage of corn grown of 122,854 acres and an average population of 28,402 , this gives a drop of $\$ 11.17 \times 122,854 / 28,402=$ $\$ 48.30$. 
at the bank level, banks thus appear unable to smooth temporary shocks to their balance sheets during the debt crisis.

We also find that exogenous shocks to cash flow have important general equilibrium labor market effects. First, we find that negative shocks to the agricultural sector during the farm debt crisis reduce both employment and wages in that sector. In addition, we find that there are spillover effects into other sectors. In particular, in counties that experience negative shocks during the crisis, employment in the services sector increases due to workers being displaced from farming, while the average wage of employees in services drops, consistent with an increase in labor supply. Overall, we find evidence that temporary shocks that affect balance sheets of firms in the agricultural sector during a crisis create externalities for other sectors.

Our results highlight the potential importance of cash injections to firms during a financial crisis when balance sheets are impaired and financial frictions are high. The results also underscore how cash injections in one sector can spill over into other sectors of the economy, both real and financial. Income multipliers during financial crises are shown to be high. Importantly, the economic impact of interventions meant to strengthen real sector balance sheets is state dependent and countercyclical, consistent with financial accelerator models. 


\section{References}

1. Allen, F., \& Gale, D. (1994). "Limited Market Participation and Volatility of Asset Prices." American Economic Review 84 (4), 933-955.

2. Allen, F., \& Gale, D. (1998). Optimal financial crises. The Journal of Finance, 53(4), 1245-1284.

3. Auerbach, A. J., \& Gorodnichenko, Y. (2012). Measuring the output responses to fiscal policy. American Economic Journal: Economic Policy, 4(2), 1-27.

4. Barnett, B.J. (2000). "The US farm financial crisis of the 1980s.” Agricultural History, 74(2), pp.366380.

5. Beck, T., Demirgüç-Kunt, A. S. L. I., \& Maksimovic, V. (2005). Financial and legal constraints to growth: Does firm size matter? The Journal of Finance, 60(1), 137-177.

6. Bernanke, B. S., \& Blinder, A. S. (1988). "Credit, Money, and Aggregate Demand." The American Economic Review, 78 (2), 435-39.

7. Bernanke, B. S., \& Gertler, M. (1989). "Agency Costs, Net Worth, and Business Fluctuations." The American Economic Review 79 (1), 14-31.

8. Bernanke, B. S., \& Gertler, M. (1995). "Inside the Black Box: The Credit Channel of Monetary Policy Transmission." The Journal of Economic Perspectives 9 (4), 27-48.

9. Brunnermeier, M.K. and Sannikov, Y. (2014). "A macroeconomic model with a financial sector." The American Economic Review, 104 (2), 379-421.

10. Calomiris, C. W., Hubbard, R. G., \& Stock, J. (1986). "The Farm Debt Crisis and Public Policy." Brookings Papers on Economic Activity 1986 (2), 441-485.

11. Chaney, T., Sraer, D., \& Thesmar, D. (2012). "The Collateral Channel: How Real Estate Shocks Affect Corporate Investment." American Economic Review 102 (6), 2381-2409.

12. Christiano, L. J., M. Eichenbaum, and S. Relebo (2011). "When is the Government Spending Multiplier Large?," Journal of Political Economy, 119(1), 78-121.

13. G. Chodorow-Reich, L. Feiveson, Z. Liscow, and W. Woolston, "Does State Fiscal Relief During Recessions Increase Employment? Evidence from the American Recovery and Reinvestment Act." American Economic Journal: Economic Policy, 4 (3), 2012, pp. 118-45.

14. Conley, T. G. (1999). GMM estimation with cross sectional dependence. Journal of Econometrics, 92(1), 1-45.

15. Conley, T. G. (2008). "Spatial Econometrics." New Palgrave Dictionary of Economics, 741-7.

16. Dell, M., Jones, B. F., \& Olken, B. (2014). "What Do We Learn from the Weather? The New 
Climate-Economy Literature." Journal of Economic Literature 52 (3), 740-98.

17. Deschênes, O., \& Greenstone, M. (2007). "The Economic Impacts of Climate Change: Evidence from Agricultural Output and Random Fluctuations in Weather." The American Economic Review 97 (1), 354-385.

18. Deschênes, O., \& Greenstone, M. (2012) "The economic impacts of climate change: Evidence from agricultural output and random fluctuations in weather: Reply." The American Economic Review 102 (7), 3761-3773.

19. Duffie, D. (2010). Presidential Address: Asset Price Dynamics with Slow-Moving Capital. The Journal of Finance, 65(4), 1237-1267.

20. Eggertsson, G. B., \& M. Woodford (2003): “The Zero Bound on Interest Rates and Optimal Monetary Policy," Brookings Papers on Economic Activity, 34(1), 139-235.

21. FDIC Division of Research and Statistics, History of the Eighties-Lessons for the Future, Volume I: An Examination of the Banking Crises of the 1980s and Early 1990s. (1997): 259-290.

22. Gertler, M., \& S. Gilchrist (1994) "Monetary Policy, Business Cycles, and the Behavior of Small Manufacturing Firms.” Quarterly Journal of Economics, 109(2), 309-340.

23. Glauber, J. W. (2013) "The growth of the federal crop insurance program, 1990-2011." American Journal of Agricultural Economics 95 (2), 482-488.

24. Hadlock, C. J., \& Pierce, J. R. (2010). New evidence on measuring financial constraints: Moving beyond the KZ index. Review of Financial Studies, 23(5), 1909-1940.

25. Harl, Neil E. The farm debt crisis of the 1980s. Iowa State University Press, 1990.

26. Hart, Chad E., and Bruce A. Babcock. "The impact of crop insurance on the Iowa economy." Iowa Ag Review 6, no. 1 (200): 1.

27. Hoppe, R. A., \& Banker, D. E. (2006). "Structure and Finances of US Farms: 2005 Family Farm Report” (No. 33895). United States Department of Agriculture, Economic Research Service.

28. Hornbeck, R. (2012). "The Enduring Impact of the American Dust Bowl: Short-and Long-Run Adjustments to Environmental Catastrophe." The American Economic Review 102: 1477-1507.

29. Kashyap, A. K., \& Stein, J. C. (2000). What do a million observations on banks say about the transmission of monetary policy?. The American Economic Review, 90 (3), 407.

30. Kiyotaki, N., \& Moore, J. (1997). Credit Cycles. The Journal of Political Economy 105 (2), 211-248.

31. Krugman, P. (1998): “It's Baaack: Japan's Slump and the Return of the Liquidity Trap,” Brookings Papers on Economic Activity, 2, 137-187. 
32. Kuethe, T. H., \& Ifft, J. (2013). The information content of farmland value surveys. Agricultural Finance Review 73 (1), 45-57.

33. Mian, A., Rao, K., \& Sufi, A. (2013). Household Balance Sheets, Consumption, and the Economic Slump. The Quarterly Journal of Economics, 128(4), 1687-1726.

34. Mian, A. \& Sufi, A. (2014). What Explains the 2007-2009 Drop in Employment? Econometrica, 82(6), pages $2197-2223$.

35. Nakamura, A. \& Steinsson, J. (2014). Fiscal Stimulus in a Monetary Union: Evidence from U.S. Regions. The American Economic Review, 104(3), pages 753-792.

36. Parker, J. A. (2011). "On measuring the effects of fiscal policy in recessions." Journal of Economic Literature, 49(3), 703-718.

37. Ramey V.A. \& S. Zubairy, "Government Spending Multipliers in Good Times and in Bad: Evidence from U.S. Historical Data," NBER Working Paper No. 20719, November 2014.

38. Schlenker, W., \& Roberts, M.J. (2006). Nonlinear Effects of Weather on Corn Yields. Applied Economic Perspectives and Policy 28 (3), 391-398.

39. Schlenker, W., \& Roberts, M.J. (2009). Nonlinear Temperature Effects Indicate Severe Damages to US Crop Yields Under Climate Change. Proceedings of the National Academy of Sciences 106 (37), 15594-15598.

40. Shleifer, A., \& Vishny, R.W. (1992). Liquidation values and debt capacity: A market equilibrium approach. The Journal of Finance 47 (4), 1343-1366.

41. Stam, Jerome M., and Bruce L. Dixon. Farmer Bankruptcies and Farm Exits in the United States, 18992002. US Department of Agriculture, Economic Research Service, 2004.

42. Stinn, M., \& Duffy, M. (2012). What is the Precision of Land Survey Values? Choices 27, 1-4. 


\section{Table 1: Summary Statistics}

This table contains summary statistics for all variables, split between crisis and non-crisis years. All variables are at the county-year level. Days Above 83 is the number of days where the average temperature is above $83^{\circ} \mathrm{F}$ during the growing season. Corn Yield is defined as bushels of corn produced per acre of harvested land. Land Value is the dollar value of farmland per acre. Income is county income-per-capita. Ag Delinquencies is the total outstanding balance of agricultural loans that are 90 days or more past-due and upon which the bank continues to accrue interest, in thousands of dollars. Statistics for the non-crisis period are presented from 1950-1980 and from 1988-2010, except for Income (which is from 1959, 1969-1980, and 1988-2010) and Ag Delinquencies (which is from 19882000). Statistics for the crisis period are presented from 1984 to 1987. All dollar amounts are scaled by the consumer price index (CPI), and are in real 2010 dollars.

Panel A: Crisis Years, 1981-1987

\begin{tabular}{lllllll}
\hline \multicolumn{1}{c}{ Variable } & \# Obs & \multicolumn{1}{c}{ Mean } & \multicolumn{1}{c}{ Std. Dev. } & \multicolumn{1}{c}{ p25 } & \multicolumn{1}{c}{ Median } & \multicolumn{1}{c}{ p75 } \\
\hline Days Above 83 & 693 & 3.25 & 4.63 & 0.50 & 1.62 & 3.73 \\
Corn Yield & 693 & 116.84 & 22.07 & 108.70 & 121.50 & 131.60 \\
Land Value & 693 & $2,947.27$ & $1,511.82$ & $1,759.38$ & $2,447.81$ & $4,055.71$ \\
Income & 693 & $24,827.96$ & $2,720.39$ & $23,093.07$ & $25,054.18$ & $26,675.79$ \\
\hline
\end{tabular}

Panel B: Crisis Years, 1984-1987

\begin{tabular}{lllllll}
\hline \multicolumn{1}{c}{ Variable } & \# Obs & \multicolumn{1}{c}{ Mean } & Std. Dev. & \multicolumn{1}{c}{ p25 } & \multicolumn{1}{c}{ Median } & \multicolumn{1}{c}{ p75 } \\
\hline Days Above 83 & 396 & 2.38 & 3.07 & 0.29 & 1.22 & 3.05 \\
Corn Yield & 396 & 123.83 & 15.21 & 115.15 & 125.75 & 134.30 \\
Land Value & 396 & $1,977.86$ & 751.78 & $1,488.39$ & $1,868.92$ & $2,299.06$ \\
Income & 396 & $25,855.09$ & $2,379.82$ & $24,558.87$ & $25,825.22$ & $27,477.96$ \\
Ag Delinquencies & 396 & 710.61 & 684.66 & 185.47 & 526.12 & $1,084.87$ \\
\hline
\end{tabular}

Panel C: Non-Crisis Years

\begin{tabular}{lllllll}
\hline \multicolumn{1}{c}{ Variable } & \# Obs & \multicolumn{1}{c}{ Mean } & \multicolumn{1}{c}{ Std. Dev. } & \multicolumn{1}{c}{ p25 } & \multicolumn{1}{c}{ Median } & \multicolumn{1}{c}{ p75 } \\
\hline Days Above 83 & 5,339 & 2.51 & 3.64 & 0.05 & 1.07 & 3.22 \\
Corn Yield & 5,346 & 105.67 & 41.48 & 71.10 & 100.70 & 139.10 \\
Land Value & 5,346 & $2,753.98$ & $1,361.00$ & $1,893.49$ & $2,424.75$ & $3,127.98$ \\
Income & 3,465 & $28,099.30$ & $6,756.46$ & $23,842.11$ & $27,490.18$ & $32,435.73$ \\
Ag Delinquencies & 1,279 & 164.90 & 276.59 & 1.26 & 54.04 & 214.88 \\
\hline
\end{tabular}


Table 2: Temperature Shocks on Corn Yields

This table provides regression results for the effects of temperature shocks on corn yields. All variables represent county-level values in the indicated year. Corn Yield is defined as bushels of corn produced per acre of harvested land. Days Above 83 is the number of days where the average temperature is above $83^{\circ} \mathrm{F}$ during the growing season. Standard errors are given in parentheses, and are corrected for spatial correlation (as in Conley 2008), as indicated. *, **, and *** indicate significance at the 10 percent, 5 percent, and 1 percent level, respectively. All regressions include an intercept term (not reported). The crisis period is defined from 1981-1987 in columns 1 and 2, and from 1984-1987 in column 3; the non-crisis period runs from 1950-1980 and 1988-2010; the full sample runs from 1950 to 2010 .

Dependent Variable: $\log ($ Corn Yield $)$

\begin{tabular}{lcc|c|c}
\hline & $(1)$ & $(2)$ & $(3)$ & $(4)$ \\
\hline Time Period: & \multicolumn{2}{c|}{ Crisis, $1981-1987$} & Crisis, 1984-1987 & Non-crisis \\
\hline Days Above 83 & $-0.034^{* * *}$ & $-0.033^{* * *}$ & $-0.022^{* * *}$ & $-0.026^{* * *}$ \\
& $(0.008)$ & $(0.008)$ & $(0.004)$ & $(0.003)$ \\
& & & & \\
Year FE & Yes & Yes & Yes & Yes \\
County FE & No & Yes & Yes & Yes \\
Standard Errors & Spatial & Spatial & Spatial & Spatial \\
Observations & 693 & 693 & 396 & 5,339 \\
$\mathrm{R}^{2}$ & 0.66 & 0.80 & 0.75 & 0.93 \\
\hline
\end{tabular}




\section{Table 3: Temperature Shocks on Land Values}

This table provides regression results for the effects of temperature shocks on farm land values. All variables represent county-level values in the indicated year. Land V alue is the dollar value of farmland per acre, in real (2010) dollars. Days Above 83 is the number of days where the average temperature is above $83^{\circ} \mathrm{F}$ during the growing season. Standard errors are given in parentheses, and are corrected for spatial correlation (as in Conley 2008), as indicated. *, **, and *** indicate significance at the 10 percent, 5 percent, and 1 percent level, respectively. All regressions include an intercept term (not reported). The crisis period is defined from 1981-1987 in columns 1 and 2, and from 1984-1987 in column 3; the non-crisis period runs from 1950-1980 and 1988-2010; the full sample runs from 1950 to 2010 .

Dependent Variable: $\log ($ Land V alue $)$

\begin{tabular}{lcc|c|c}
\hline & $(1)$ & $(2)$ & $(3)$ & $(4)$ \\
\hline Time Period: & \multicolumn{2}{c|}{ Crisis, 1981-1987 } & Crisis, 1984-1987 & Non-crisis \\
\hline Days Above 83 & $-0.031^{* * *}$ & $-0.004^{* * *}$ & $-0.007 * * *$ & -0.001 \\
& $(0.008)$ & $(0.001)$ & $(0.002)$ & $(0.001)$ \\
& & & & \\
Year FE & Yes & Yes & Yes & Yes \\
County FE & No & Yes & Yes & Yes \\
Standard Errors & Spatial & Spatial & Spatial & Spatial \\
Observations & 693 & 693 & 396 & 5,339 \\
$\mathrm{R}^{2}$ & 0.71 & 0.996 & 0.99 & 0.98 \\
\hline
\end{tabular}


Table 4: Temperature Shocks, Instrumental Variable Regressions during the Crisis This table provides instrumental variable regression results for the effects of temperature shocks on corn yields and land values during the farm debt crisis. All variables represent county-level values in the indicated year. Corn Yield is defined as bushels of corn produced per acre of harvested land. Land $V$ alue is the dollar value of farmland per acre, in real (2010) dollars. Days Above 83 is the number of days where the average temperature is above $83^{\circ} \mathrm{F}$ during the growing season. $\log ($ Yield $)$ is instrumented $\log$ corn yield. Standard errors are given in parentheses, and are clustered at the year level. *, **, and ${ }^{* * *}$ indicate significance at the 10 percent, 5 percent, and 1 percent level, respectively. All regressions include an intercept term (not reported).

\begin{tabular}{|c|c|c|c|c|}
\hline & (1) & (2) & (3) & (4) \\
\hline Time Period: & \multicolumn{2}{|c|}{ 1981-1987 } & \multicolumn{2}{|c|}{ 1984-1987 } \\
\hline IV Stage: & First Stage & Second Stage & First Stage & Second Stage \\
\hline Dependent Variable: & $\log ($ Corn Yield $)$ & $\log ($ Land Value $)$ & $\log ($ Corn Yield $)$ & $\log ($ Land Value $)$ \\
\hline Days Above 83 & $\begin{array}{c}-0.033^{* * *} \\
(0.004)\end{array}$ & & $\begin{array}{c}-0.022^{* * *} \\
(0.002)\end{array}$ & \\
\hline $\operatorname{log(\text {Yield})}$ & & $\begin{array}{c}0.114^{* * *} \\
(0.031)\end{array}$ & & $\begin{array}{c}0.330 * * * \\
(0.057)\end{array}$ \\
\hline Year FE & Yes & Yes & Yes & Yes \\
\hline County FE & Yes & Yes & Yes & Yes \\
\hline Observations & 693 & 693 & 396 & 396 \\
\hline $\mathrm{R}^{2}$ & 0.80 & 0.996 & 0.75 & 0.99 \\
\hline
\end{tabular}


Table 5: Agricultural Loan Delinquencies and Bank Failures

This table provides second-stage instrumental variable regression results for the effects of temperature shocks on bank failure rate during the farm debt crisis and non-crisis years. All variables represent county-level values in the indicated year. Ag Delinquencies is the outstanding balance of agricultural loans that are 90 days or more past-due and upon which the bank continues to accrue interest, in real (2010) dollars. Bank Failure is a dummy variable that takes a value of 1 if there was a bank failure in the given year, and 0 otherwise. Bank Failure Crisis is a dummy variable which takes a value of 1 if there was a bank failure from the given year until the end of the crisis, and 0 otherwise. $\operatorname{log(Yield)}$ is instrumented log corn yield. Standard errors are given in parentheses, and are clustered at the year level. *, **, and $* * *$ indicate significance at the 10 percent, 5 percent, and 1 percent level, respectively. All regressions include an intercept term (not reported). Panel A runs from 1984 to 1987, the peak of the farm debt crisis, while Panel B runs from 1988-2000 for column 1 and from 1950 to 1980 and 1988-2010 for column 2, periods outside the farm debt crisis.

Panel A: Crisis

\begin{tabular}{lccc}
\hline & $(1)$ & $(2)$ & $(3)$ \\
\hline Dependent Variable: & $\log ($ Ag Delinquencies $)$ & Bank Failure & Bank Failure Crisis \\
\hline $\log$ (Yield) & $-3.249^{* * *}$ & $-0.324^{* *}$ & $-0.402^{* * *}$ \\
& $(0.836)$ & $(0.144)$ & $(0.064)$ \\
Year FE & & & \\
County FE & Yes & Yes & Yes \\
Observations & Yes & Yes & Yes \\
$\mathrm{R}^{2}$ & 396 & 396 & 396 \\
\hline
\end{tabular}

Panel B: Non-Crisis

\begin{tabular}{lcc}
\hline & $(1)$ & $(2)$ \\
\hline Dependent Variable: & $\log ($ Ag Delinquencies $)$ & Bank Failure \\
\hline $\log$ (Yield $)$ & -0.707 & 0.015 \\
& $(1.276)$ & $(0.022)$ \\
Year FE & & \\
County FE & Yes & Yes \\
Observations & Yes & Yes \\
$\mathrm{R}^{2}$ & 1,273 & 5,339 \\
\hline
\end{tabular}




\section{Table 6: Agricultural Wages and Employment}

This table provides second-stage instrumental variable regression results for the effects of temperature shocks on agricultural wages and employment during the farm debt crisis and non-crisis years. All variables represent county-level values in the indicated year. Ag Employment is the total employment in agricultural crop production. $A g A v g$ age is the average annual wage for an individual in agricultural crop production. $A g$ Total Wages is the sum total of all wages for agricultural crop production. $\overline{\log (\text { Yield })}$ is instrumented log corn yield. All dollar amounts are in real (2010) dollars. Standard errors are given in parentheses, and are clustered at the year level. *,**, and *** indicate significance at the 10 percent, 5 percent, and 1 percent level, respectively. All regressions include an intercept term (not reported). Panel A runs from 1984 to 1987, the peak of the farm debt crisis, while Panel B runs from 1975-1980 and from 1988-2000, the period outside the farm debt crisis.

Panel A: Crisis

\begin{tabular}{l|ccc}
\hline & $(1)$ & $(2)$ & $(3)$ \\
\hline Sector: & \multicolumn{3}{c}{ Agricultural Crop Production } \\
\hline Dependent Variable: & Ag Employment & $\log (A g$ Avg Wage $)$ & $\log ($ Ag Total Wages $)$ \\
\hline log(Yield) & $29.96^{* *}$ & $2.87^{* *}$ & $4.37^{* *}$ \\
& $(14.73)$ & $(1.36)$ & $(2.01)$ \\
& & & \\
Year FE & Yes & Yes & Yes \\
County FE & Yes & Yes & Yes \\
Observations & 396 & 396 & 396 \\
$\mathrm{R}^{2}$ & 0.66 & 0.75 & 0.74 \\
\hline
\end{tabular}

Panel B: Non-Crisis

\begin{tabular}{l|ccc}
\hline & $(1)$ & $(2)$ & $(3)$ \\
\hline Sector: & \multicolumn{3}{c}{ Agricultural Crop Production } \\
\hline Dependent Variable: & Ag Employment & $\log (A g$ Avg Wage $)$ & $\log ($ Ag Total Wages $)$ \\
\hline log(Yield) & -6.39 & 1.13 & 1.42 \\
& $(7.15)$ & $(0.92)$ & $(1.18)$ \\
& & & \\
Year FE & Yes & Yes & Yes \\
County FE & Yes & Yes & Yes \\
Observations & 1,875 & 1,875 & 1,875 \\
$\mathrm{R}^{2}$ & 0.37 & 0.44 & 0.45 \\
\hline
\end{tabular}




\section{Table 7: Wages and Employment in the Services Sector}

This table provides second-stage instrumental variable regression results for the effects of temperature shocks on wages and employment in the services sector during the farm debt crisis and non-crisis years. All variables represent county-level values in the indicated year. Services Employ is the total employment in the services sector. Services $A v g W$ age is the average annual wage for an individual in the services sector. Services Total Wages is the sum total of all wages for the services sector. $\operatorname{log(Yield)}$ is instrumented log corn yield. All dollar amounts are in real (2010) dollars. Standard errors are given in parentheses, and are clustered at the year level. *, **, and *** indicate significance at the 10 percent, 5 percent, and 1 percent level, respectively. All regressions include an intercept term (not reported). Panel A runs from 1984 to 1987, the peak of the farm debt crisis, while Panel B runs from 1975-1980 and from 1988-2000, the period outside the farm debt crisis.

Panel A: Crisis

\begin{tabular}{l|ccc}
\hline & $(1)$ & $(2)$ & $(3)$ \\
\hline Sector: & \multicolumn{3}{c}{ Services Sector } \\
\hline Dependent Variable: & Services Employ & $\begin{array}{c}\log (\text { Services } \\
\text { Avg Wage })\end{array}$ & $\begin{array}{c}\log \text { (Services } \\
\text { Total W ages })\end{array}$ \\
\hline log(Yield) & $-720.71^{* * *}$ & $0.075^{* *}$ & -0.002 \\
& $(106.57)$ & $(0.033)$ & $(0.045)$ \\
Year FE & & & \\
County FE & Yes & Yes & Yes \\
Observations & Yes & Yes & Yes \\
$\mathrm{R}^{2}$ & 396 & 396 & 396 \\
\hline
\end{tabular}

Panel B: Non-Crisis

\begin{tabular}{l|ccc}
\hline & $(1)$ & $(2)$ & $(3)$ \\
\hline Sector: & \multicolumn{3}{c}{ Services Sector } \\
\hline Dependent Variable: & Services Employ & $\begin{array}{c}\log (\text { Services } \\
\text { Avg Wage })\end{array}$ & $\begin{array}{c}\log \text { (Services } \\
\text { Total Wages })\end{array}$ \\
\hline log(Yield) & -158.73 & 0.074 & 0.063 \\
& $(715.69)$ & $(0.098)$ & $(0.159)$ \\
Year FE & & & \\
County FE & Yes & Yes & Yes \\
Observations & Yes & Yes & Yes \\
$\mathrm{R}^{2}$ & 1,875 & 1,875 & 1,875 \\
\hline
\end{tabular}




\section{Table 8: Services Employment and Dependence on Farm Income}

This table provides regression results for the effects of temperature shocks on services sector employment, and how the magnitude of the effect varies based on the county's dependence on farm income during the crisis. Panel A runs an interaction regression with a measure of farm dependence, while Panel B separates the sample into counties with either high or low farm dependence and runs instrumental variable specifications for each (second-stage results are provided). All variables represent county-level values in the indicated year. Services Employ is the total employment in the services sector. Services Avg $W$ age is the average annual wage for an individual in the services sector. Days Above 83 is the number of days where the average temperature is above $83^{\circ} \mathrm{F}$ during the growing season. Farm Income Pct is percentage of total county income that is comprised of farm crop income, taken as an average from 1969-1980. $\log$ (Yield $)$ is instrumented log corn yield. All regressions are run from 1984-1987. Standard errors are given in parentheses, and are corrected for spatial correlation in Panel A (as in Conley, 2008). ${ }^{*}, * *$, and $* * *$ indicate significance at the 10 percent, 5 percent, and 1 percent level, respectively. All regressions include an intercept term (not reported).

\begin{tabular}{l|cc}
\multicolumn{2}{c}{ Panel A: Interaction with Dependence on Farm Income } \\
\hline & $(1)$ & $(2)$ \\
\hline Dependent Variable: & Services Employ & $\log ($ Services \\
& & Avg Wage $)$ \\
\hline Days Above 83 & $55.91^{* * *}$ & $-0.003^{* * *}$ \\
& $(21.59)$ & $(0.0002)$ \\
Days Above 83 & $-234.72^{* * *}$ & 0.008 \\
$\times$ Farm Income Pct & $(81.84)$ & $(0.007)$ \\
& & \\
Year FE & Yes & Yes \\
County FE & Yes & Yes \\
Standard Errors & Spatial & Spatial \\
Observations & 396 & 396 \\
$\mathrm{R}^{2}$ & 0.997 & 0.963 \\
\hline
\end{tabular}

Panel B: Instrumental Variable Regressions

\begin{tabular}{|c|c|c|c|c|}
\hline & (1) & $(2)$ & (3) & (4) \\
\hline & $\begin{array}{l}\text { Below- } \\
\text { Farm Income }\end{array}$ & $\begin{array}{l}\text { dian } \\
\text { ependence }\end{array}$ & $\begin{array}{r}\text { Abc } \\
\text { Farm Inc }\end{array}$ & Dedian \\
\hline Dependent Variable: & Services Employ & $\begin{array}{l}\log (\text { Services } \\
\text { Avg Wage })\end{array}$ & $\begin{array}{l}\text { Services } \\
\text { Employ }\end{array}$ & $\begin{array}{l}\log (\text { Services } \\
\text { Avg Wage })\end{array}$ \\
\hline $\operatorname{log(\text {Yield})}$ & $\begin{array}{c}-667.17 * * \\
(272.54)\end{array}$ & $\begin{array}{c}0.105^{* * *} \\
(0.037)\end{array}$ & $\begin{array}{l}66.87^{*} \\
(37.11)\end{array}$ & $\begin{array}{l}0.0417 \\
(0.067)\end{array}$ \\
\hline Year FE & Yes & Yes & Yes & Yes \\
\hline County FE & Yes & Yes & Yes & Yes \\
\hline Observations & 196 & 196 & 200 & 200 \\
\hline $\mathrm{R}^{2}$ & 0.997 & 0.976 & 0.992 & 0.916 \\
\hline
\end{tabular}


Table 9: Temperature Shocks and County Income

This table provides regression results for the effects of temperature shocks on county income per capita. Columns 1 and 2 provide results from an instrumental variable specification, while Columns 3 and 4 provide reduced-form results. All variables represent county-level values in the indicated year. $\log$ (Income) is log income-per-capita (in real 2010 dollars). $\log$ (Yield) is instrumented log corn yield. Days Above 83 is the number of days where the average temperature is above $83^{\circ} \mathrm{F}$ during the growing season. The crisis period runs from 1984 to 1987, the peak of the farm debt crisis. The non-crisis period includes 1969-1980 and 1988-2010. Standard errors are given in parentheses and are clustered at the year level in Columns 1 and 2 and are corrected for spatial correlation (as in Conley, 2008) in Columns 3 and 4 as indicated. *, **, and *** indicate significance at the 10 percent, 5 percent, and 1 percent level, respectively. All regressions include an intercept term (not reported).

Dependent Variable: $\log$ (Income)

\begin{tabular}{l|cccc}
\hline & $(1)$ & $(2)$ & $(3)$ & $(4)$ \\
\hline Time Period: & Crisis & Non-crisis & Crisis & Non-crisis \\
\hline log(Yield) & $0.138^{* * *}$ & 0.034 & & \\
& $(0.051)$ & $(0.031)$ & & \\
Days Above 83 & & & $-0.003^{* * *}$ & -0.001 \\
& & & $(0.001)$ & $(0.001)$ \\
Year FE & & & & \\
County FE & Yes & Yes & Yes & Yes \\
Standard Errors & Yes & Yes & Yes & Yes \\
Observations & 396 & Robust & Spatial & Spatial \\
$\mathrm{R}^{2}$ & 0.95 & 0.95 & 396 & 3,557 \\
\hline
\end{tabular}


Figure 1: Distribution of Temperature Shocks

This figure shows the distribution of temperature shocks during the growing season, for the entire sample from 1950 to 2010. The vertical axis represents the density, while the horizontal axis gives the number of days in the growing season for a given county-year that were above $83^{\circ} \mathrm{F}$.

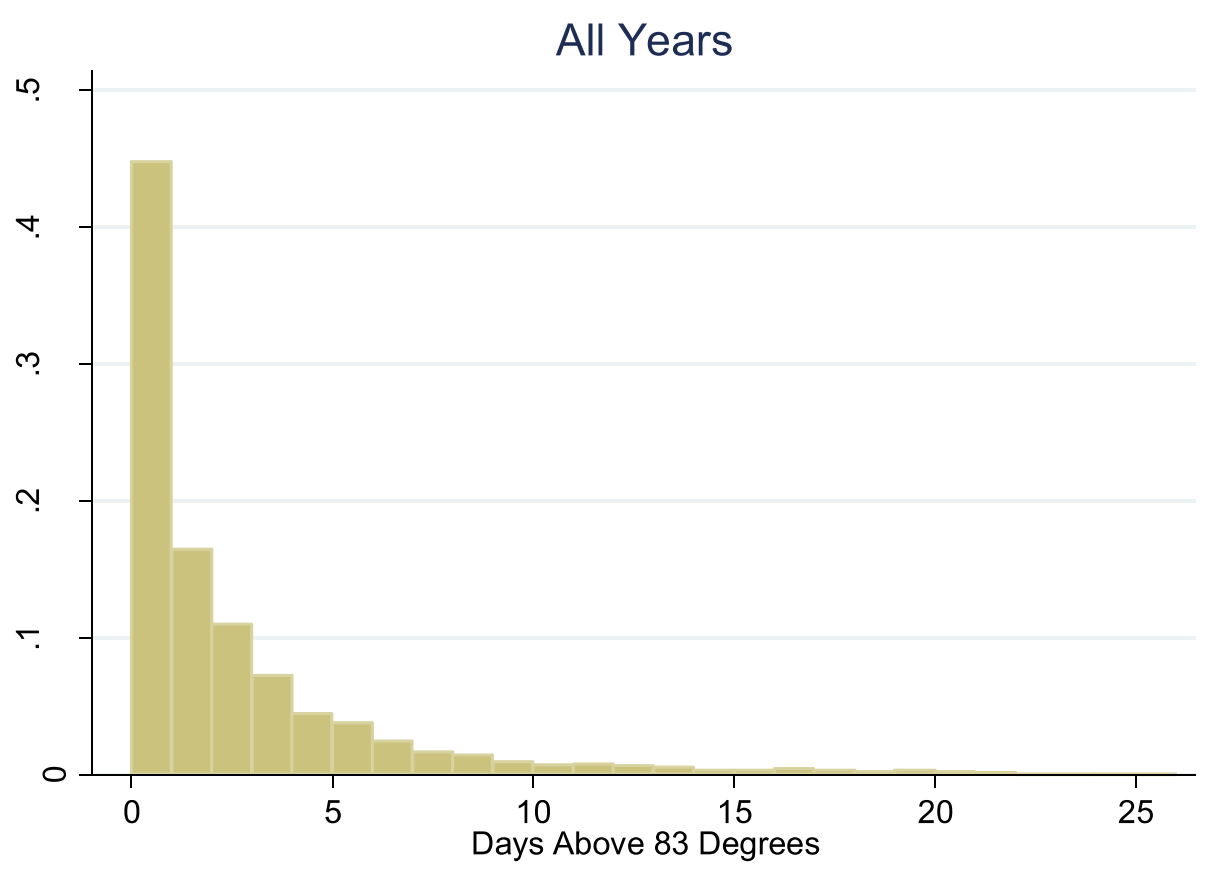


Figure 2: Distribution of Temperature Shocks in Excess of Averages

This figure shows the distribution of temperature shocks during the growing season, in excess of county and yearly averages, for the entire sample from 1950 to 2010. The vertical axis represents the density, while the horizontal axis gives the de-meaned number of days in the growing season for a given county-year that were above $83^{\circ} \mathrm{F}$.

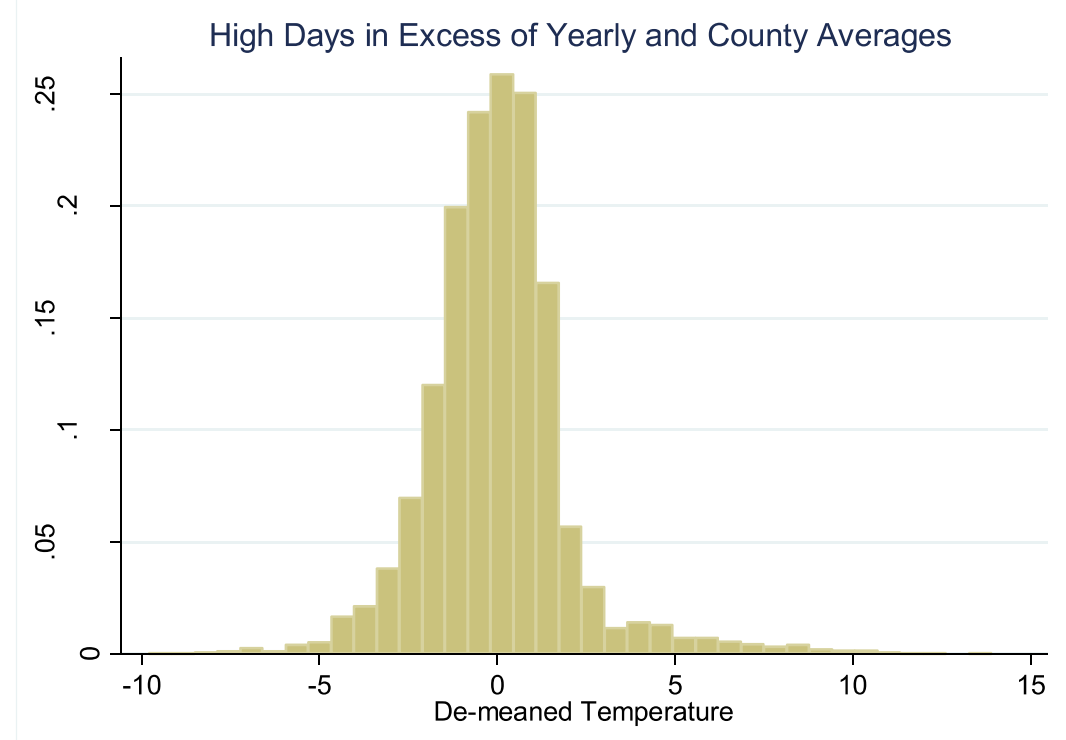


Figure 3: Distribution of Temperature Shocks in Different Years

This figure shows the distribution of temperature shocks during the growing season, for various years. In each graph, the vertical axis represents the density, while the horizontal axis gives the number of days in the growing season for a given county in the indicated year that were above $83^{\circ} \mathrm{F}$.
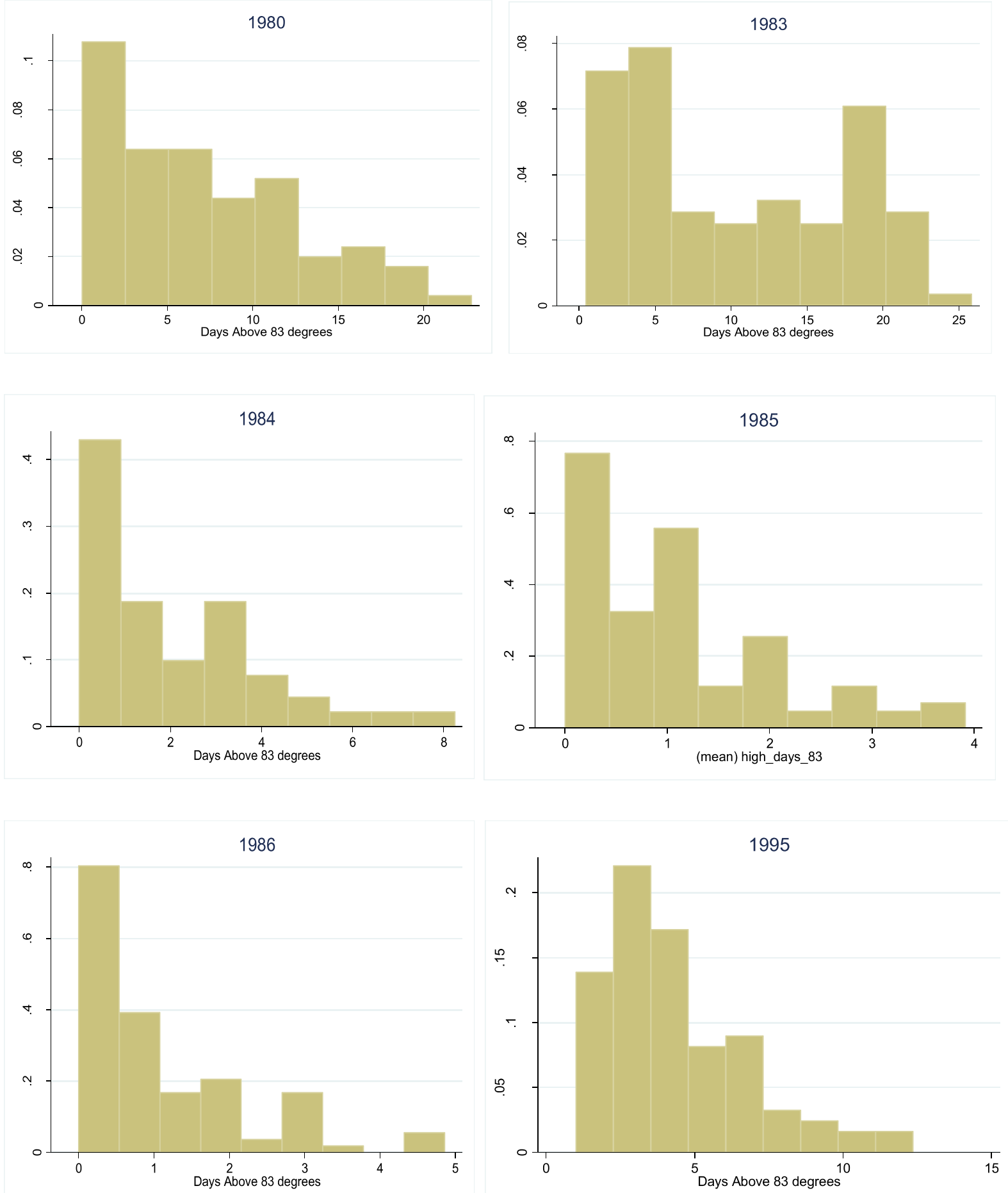
Figure 4: Corn Yields, Farm Land Values, and Agricultural Debt over Time

This figure depicts average corn yields, land values, and agricultural debt over time. Each data point is an average across all counties in Iowa. Corn yield is defined as bushels of corn produced per acre of harvested land. Land Value is the dollar value of farmland per acre, in real (2010) dollars. Total agricultural debt is the sum of agricultural loans to finance production and real estate debt secured by farmland, in real (2010) dollars.
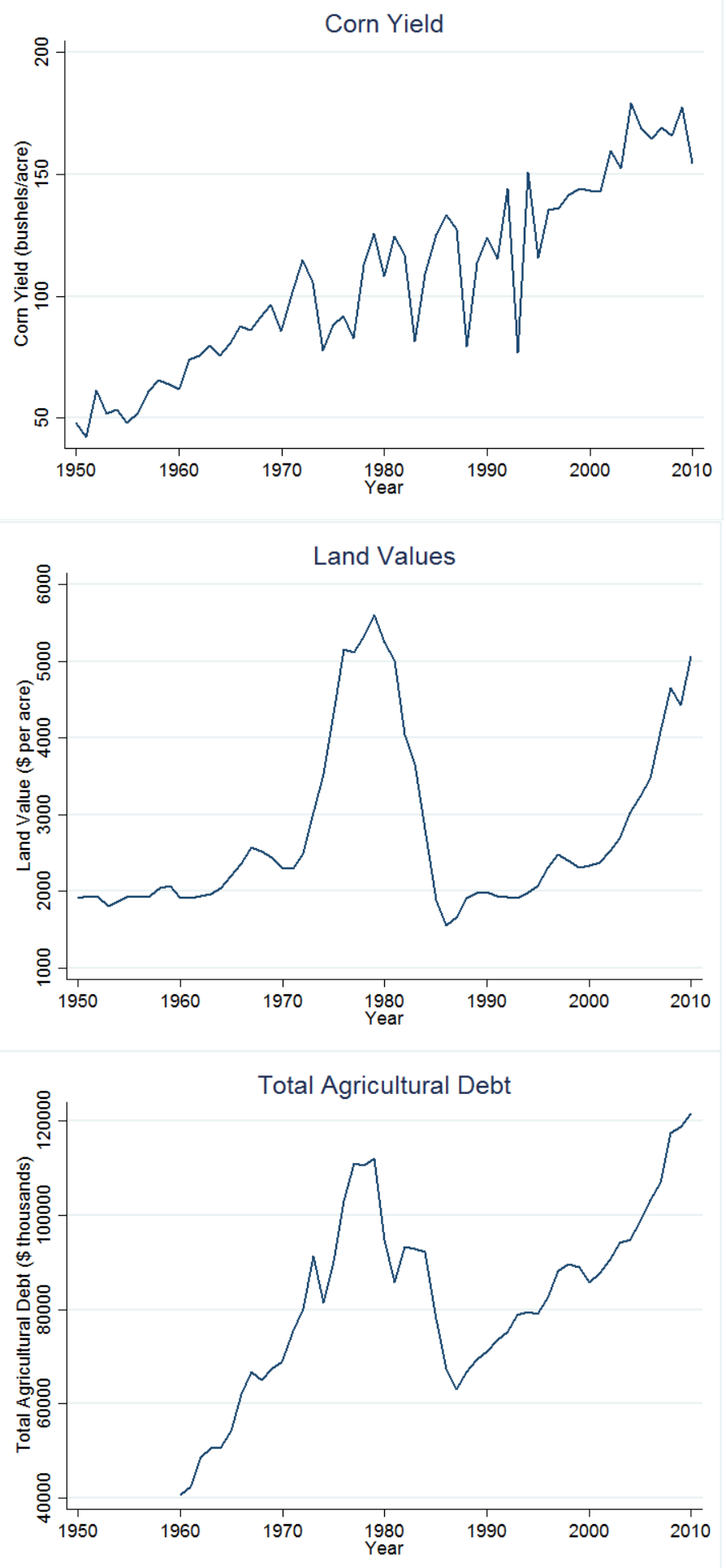
Figure 5: Cross-county Land Purchases in Hamilton County

This figure depicts cross-county land purchases in Hamilton County - purchases where the buyer is located outside of the county. The red horizontal line indicates the mean over the sample period.

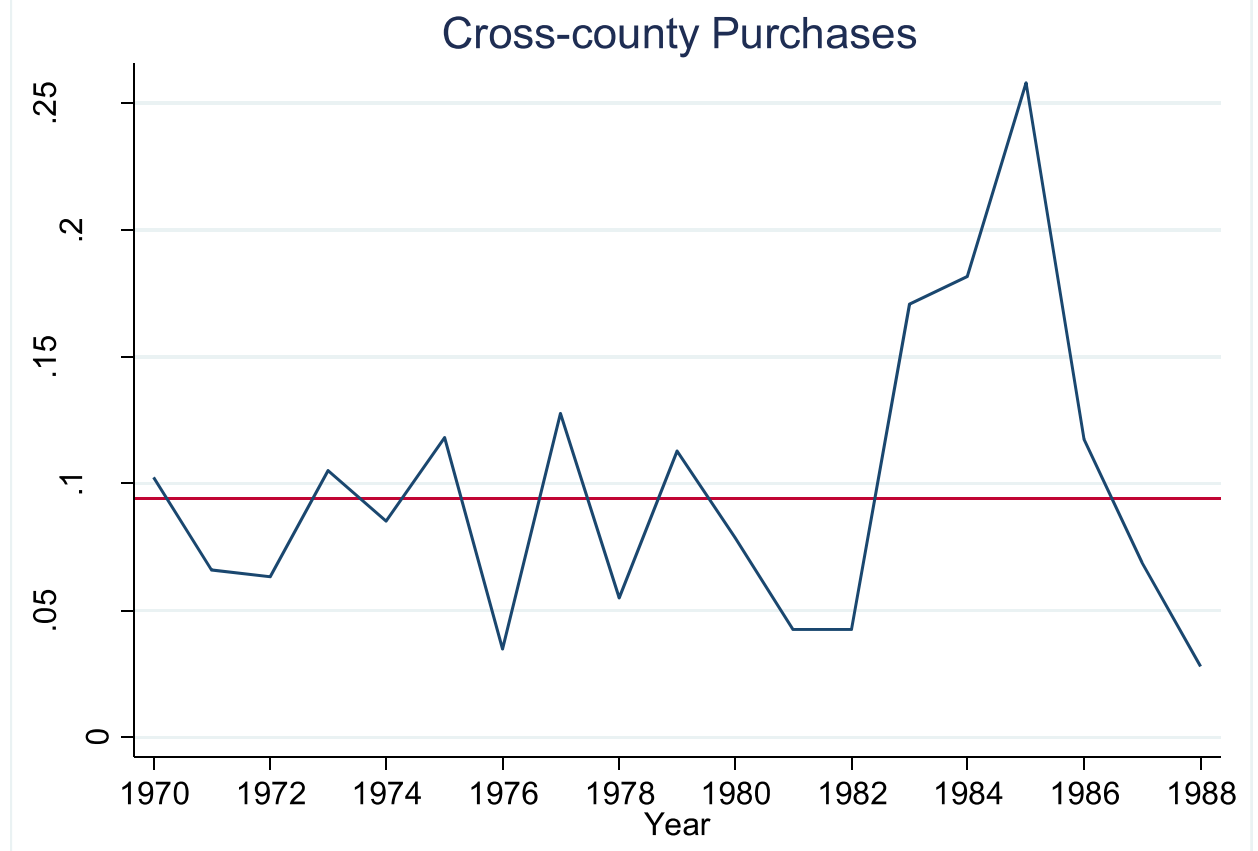

